\title{
Review \\ Performance Efficiency of Conventional Treatment Plants and Constructed Wetlands towards Reduction of Antibiotic Resistance
}

\author{
Moushumi Hazra ${ }^{1, *}$ and Lisa M. Durso ${ }^{2}$ \\ 1 Department of Hydrology, Indian Institute of Technology, Roorkee 247667, Uttarakhand, India \\ 2 Agroecosystem Management Research Unit, Agricultural Research Service, United States Department of \\ Agriculture, Lincoln, NE 68583, USA; lisa.durso@ars.usda.gov \\ * Correspondence: moushumi.pd@hy.iitr.ac.in or moushmihazra@gmail.com; Tel.: +91-9162155685
}

Citation: Hazra, M.; Durso, L.M. Performance Efficiency of Conventional Treatment Plants and Constructed Wetlands towards

Reduction of Antibiotic Resistance. Antibiotics 2022, 11, 114. https://doi.org/10.3390/ antibiotics11010114

Academic Editor: Jie Fu

Received: 28 November 2021

Accepted: 12 January 2022

Published: 16 January 2022

Publisher's Note: MDPI stays neutral with regard to jurisdictional claims in published maps and institutional affiliations.

Copyright: (C) 2022 by the authors. Licensee MDPI, Basel, Switzerland. This article is an open access article distributed under the terms and conditions of the Creative Commons Attribution (CC BY) license (https:// creativecommons.org/licenses/by/ $4.0 /)$.

\begin{abstract}
Domestic and industrial wastewater discharges harbor rich bacterial communities, including both pathogenic and commensal organisms that are antibiotic-resistant (AR). AR pathogens pose a potential threat to human and animal health. In wastewater treatment plants (WWTP), bacteria encounter environments suitable for horizontal gene transfer, providing an opportunity for bacterial cells to acquire new antibiotic-resistant genes. With many entry points to environmental components, especially water and soil, WWTPs are considered a critical control point for antibiotic resistance. The primary and secondary units of conventional WWTPs are not designed for the reduction of resistant microbes. Constructed wetlands (CWs) are viable wastewater treatment options with the potential for mitigating AR bacteria, their genes, pathogens, and general pollutants. Encouraging performance for the removal of AR (2-4 logs) has highlighted the applicability of CW on fields. Their low cost of construction, operation and maintenance makes them well suited for applications across the globe, especially in developing and low-income countries. The present review highlights a better understanding of the performance efficiency of conventional treatment plants and CWs for the elimination/reduction of AR from wastewater. They are viable alternatives that can be used for secondary/tertiary treatment or effluent polishing in combination with WWTP or in a decentralized manner.
\end{abstract}

Keywords: conventional treatment plants; wastewater; treated effluent; constructed wetlands; antibiotic-resistant genes/bacteria; macrophytes

\section{Introduction}

Wastewater treatment plants (WWTPs) are a central distribution point where effluents are distributed to receiving water bodies. WWTPs are efficient for the reduction of many pollutants but have not shown efficiency for the removal of antibiotic-resistant bacteria (ARB) and antibiotic-resistant genes (ARGs) [1,2]. Municipal wastewater contains a rich microbial community derived from feces and other sources, including both naturally occurring and anthropogenically enriched ARBs, along with unmetabolized drugs and their metabolites which are secreted in urine and feces [3,4]. The presence of heavy metals, antibiotic residues, and other emerging contaminants add to the load in WWTP that facilitates conditions for horizontal gene transfer and accelerates the development of ARB, including uptake of ARGs by pathogens. WWTP effluents and biosolids are directly discharged to water bodies, agricultural lands, or soil, and there is growing evidence that treated effluents transport ARBs and ARGs through surface runoff, discharge to water bodies and percolating into groundwater [5,6].

The United Nations Environment Programme identifies antibiotic resistance among the top emerging issues of concern [7], and the human health and economic impacts have 
been well documented [8]. The development of antibiotic resistance is a natural evolutionary process mediated by microorganisms and accelerated by selective pressures due to anthropogenic activities [9]. For example, the soil is a natural reservoir of ARBs and ARGs with potential impacts on human health [10], but ARB and ARG targets are enriched in soils following the application of biosolids or animal manures [11,12]. ARGs have been detected in many environmental compartments, including in river water [13], sediment [14], soil [15,16], and both the Antarctic and Arctic ecosystem [17-19]. Hotspots for the enrichment of antibiotic resistance include not only medical settings but also environmental compartments that are subjected to anthropogenic pressure [20], such as urban and municipal wastewater systems, pharmaceutical manufacturing effluents [21], aquaculture facilities and animal husbandry facilities [22]. Like municipal wastewater, rural and agricultural wastewater is also characterized by high bacterial loads coupled with excreted antibiotics, and it contributes to the discharge of ARB and ARGs into the environment [23]. One key challenge in regards to municipal, industrial and agricultural wastewaters is that they have many entry points into the environment. Figure 1 highlights the source, development, pathway and potential threat of antibiotic resistance on the environment and application of constructed wetlands for reduction of the same.

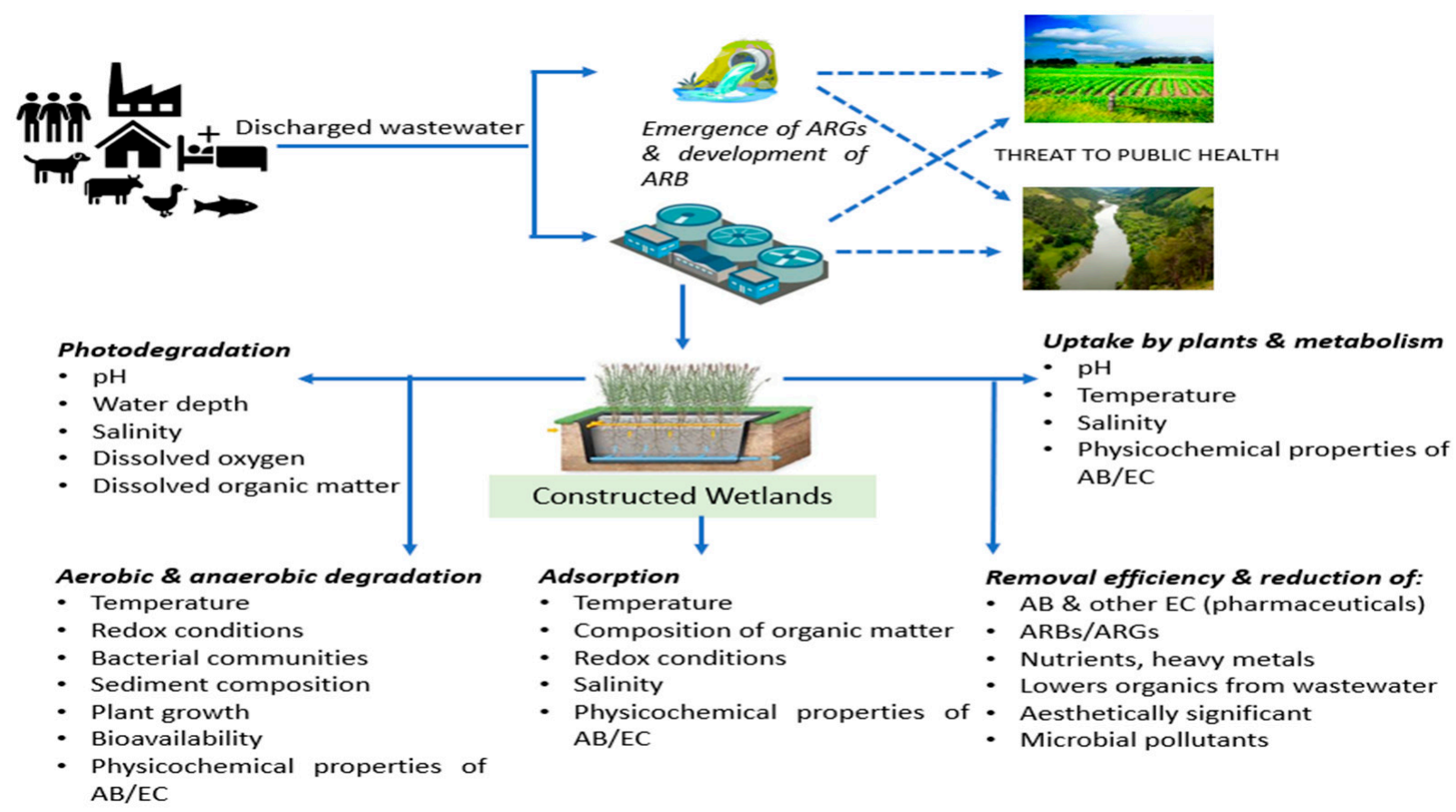

Figure 1. Source, development, pathway and potential threats of ARB/ARGs on the environment, and application of constructed wetlands through various mechanisms for the reduction of the same (Note: ARGs—antibiotic resistant genes; ARB—antibiotic resistant bacteria; AB-antibiotics, EC-emerging contaminants).

Constructed wetlands (CWs) are a sustainable "green" wastewater treatment option that can be used as an alternative to WWTP or as a component of conventional WWTP. They use natural processes, including substrates, plants, soils, and microbes, to filter and treat pollutants in water. Recent studies on CWs have gained significance due to their ability to treat pharmaceuticals $[24,25]$ from municipal and hospital wastewater $[26,27]$. There is evidence to suggest that CWs can be an effective mitigation strategy for antibiotic drugs [28], ARB, and ARGs [29,30], as well as organic pollutants and heavy metals [31,32] that have also been postulated to select for antibiotic resistance [33]. CWs can be used alone or even after primary treatment, and they have been reported to show a $2 \log$ [34] to $4 \log$ reduction [35] of pathogens with various configurations and designs resulting in different removal efficiencies. When coupled as secondary/tertiary units to primary treatment in 
WWTP, CWs assist in enhancing the performance of the WWTP [36]. On the basis of path flow / hydrology, CWs are classified as vertical flow (VFCW), horizontal subsurface flow (HSSFCW), surface flow (SFCW), and hybrid systems, generally known as integrated flow CW (IFCW) [37]. Supplementary Figure S1 represents the various types of CWs according to design, specification and types of plant species used.

There is growing interest in the functionality of CWs for the reduction of antibiotic drugs [38,39], ARBs [40], and ARGs [41]. Recent studies have focused on the use of CWs for the polishing of effluents from conventional treatment plants, aiming to achieve the further reduction of antibiotic residues [42] and coliforms [43-45]. The construction, operation and maintenance costs are significantly lower when compared to conventional WWTP options [46], making CW an economical and practical option, especially for developing/lowincome countries [47]. Another added advantage is that CWs can be used as a decentralized option both in rural and urban areas, providing aesthetically pleasing sites that promote biodiversity and provide wildlife habitats with minimum daily upkeep requirements [48]. As such, CWs contribute to multiple UN sustainable development goals, including clean water and sanitation, good health and well-being, industry innovation and infrastructure, sustainable cities and communities, life on land, and life below water [49].

Given the urgent need to sustainably address antibiotic resistance, the potential for wastewater treatments as an antibiotic resistance critical control point, and encouraging data gathered to date on the potential of CWs for mitigating antibiotic drugs, ARB and ARGs in the waste stream, the present study was conducted with the specific objective to review and explore the performance efficiency of CWs towards multiple measures of antibiotic resistance, identify the major advantages/benefits CWs provide to the environment and compare CWs with conventional treatment plants for the reduction of antibiotic-resistant targets and other microbial pollutants. The present study will therefore provide a backbone for better understanding and evaluating the challenges faced by developing/low-income countries when managing and disposing of their huge amounts of wastewater, with a focus on antibiotic resistance outcomes.

\section{Methods}

\subsection{General Approach}

In order to understand the major problems associated with the disposal of wastewater in the context of antibiotic resistance in developing/low-income countries and to identify knowledge and research gaps, a literature search was conducted. We considered recently published articles for the abundance of ARGs in different environments between 2016-2021 and also included some significant studies reported during 1981-2015. The keywords used were CW AND ARGs AND bacteria AND WWTP AND mechanism of ARB in CWs AND AR in sludge AND AR in WWTP. Initially, articles and reviews based on effluents discharged from treatment plants (with/without tertiary units and chlorination), their characteristics and their impact on the environment were identified. We were also focused on antibiotic resistance associated with WWTPs, sludge being used as fertilizers without any post-treatment, CWs, treated effluents (both from treatment plants and CWs) and their effect on the receiving water bodies. There are no discharge standards for AR for effluents that are being directly discharged to water bodies and agricultural land for irrigation. Moreover, there is ignorance regarding the treatment of sludge used as fertilizer or disposed to nearby land. Then the question of concern/interest was framed in a detailed manner, reviewing the significance of each point dealt with in the study and its significance (Table 1). The performance and the mechanism taking place in CWs were studied in detail through the reconnaissance of literature as described below. 
Table 1. Description of the question of concern for the present review study related to antibiotic resistance in wastewater and the use of constructed wetlands in reducing the loads from treated effluents.

\begin{tabular}{|c|c|c|}
\hline Q1. Protocols for AR & $\begin{array}{l}\text { Q2. Treatment of WW, Sludge and Discharge } \\
\text { of Effluents }\end{array}$ & Q3. Use of Natural Treatment System \\
\hline $\begin{array}{l}\text { What are the protocols/interventions } \\
\text { implemented in India for the control of AR in } \\
\text { the environment? }\end{array}$ & $\begin{array}{l}\text { What are the technologies that assist in } \\
\text { reducing the load of pollutants from } \\
\text { wastewater? Are they able to reduce } \\
\text { antibiotics, ARB and ARG load? }\end{array}$ & $\begin{array}{l}\text { Are CWs efficient enough for the control of } \\
\text { antibiotic resistance from the effluent of } \\
\text { treatment plants? How effective is it, and can } \\
\text { they be implemented at a larger scale? }\end{array}$ \\
\hline \multicolumn{3}{|l|}{ Source: } \\
\hline $\begin{array}{l}\text { National action plan on antimicrobial } \\
\text { resistance (2017) }\end{array}$ & $\begin{array}{l}\text { WW and sludge generated through urban } \\
\text { sectors in both liquid and solid state or a } \\
\text { mixture of both } \\
\text { Main pollutants: antibiotic drugs, ARG/ARB }\end{array}$ & $\begin{array}{l}\text { Any water matrix contaminated through } \\
\text { domestic and industrial wastewater, e.g., } \\
\text { ponds, lakes, rivers, canals } \\
\text { Main pollutant: antibiotic drugs, ARG/ARB }\end{array}$ \\
\hline \multicolumn{3}{|l|}{ Primary objective: } \\
\hline $\begin{array}{l}\text { Effective understanding of AMR through } \\
\text { trainings, awareness and practice of health } \\
\text { care in the community } \\
\text { Optimize the use of antibiotics / antimicrobials } \\
\text { in veterinary and human use through } \\
\text { awareness, stewardship, and effective } \\
\text { regulatory mechanisms for markets } \\
\text { Promote innovations and research on AMR } \\
\text { and collaborate with international } \\
\text { organizations }\end{array}$ & $\begin{array}{l}\text { Treatment of WW: primary, secondary and } \\
\text { tertiary treatment through conventional } \\
\text { methods in WWTP, as well as aerobic or } \\
\text { anaerobic digestion } \\
\text { Post-treatment of sludge: drying [50], } \\
\text { vermicomposting [51-53], liming [54] }\end{array}$ & $\begin{array}{l}\text { Use of NTS for efficient reduction of coliforms } \\
\text { and AR from effluents of conventional } \\
\text { treatment technologies [55] } \\
\text { Various designs and configurations, use of } \\
\text { substrates and plant species assist in better } \\
\text { removal [56] }\end{array}$ \\
\hline \multicolumn{3}{|l|}{ Pathways of exposureldisposal: } \\
\hline $\begin{array}{l}\text { Veterinary and human uses, wastewater from } \\
\text { domestic and industrial discharges, } \\
\text { agricultural runoff }\end{array}$ & $\begin{array}{l}\text { Treated effluents can be polished if CWs are } \\
\text { coupled as tertiary units in WWTP [57] } \\
\text { CW further assist in reducing the pollutant } \\
\text { load of pathogens, bacteria, coliform, } \\
\text { ARG/ARB [58] and other emergent pollutants } \\
\text { like pesticides, antibiotics }[59,60]\end{array}$ & $\begin{array}{l}\text { Disposal of treated effluent for multifarious } \\
\text { uses such as reuse in toilets, aquaculture, } \\
\text { gardening and agricultural purposes [61], } \\
\text { direct discharge to water bodies, recharge to } \\
\text { groundwater [62] }\end{array}$ \\
\hline
\end{tabular}

\section{AR in the environment:}

Wastewater treatment plants, sludge, effluent discharges from pharmaceutical industries, domestic and other industrial wastewater, hospital discharges, agricultural runoff, poultry and veterinary wastes, swine and feedlot wastewater, soil and sediments

\section{Types of recent studies in AR:}

Clinical studies: case studies on humans, animals, plants

Environmental studies: laboratory and field-based studies on water, soil, agricultural farms, poultry, review of previous study and comparative study involving effects of anthropogenic activities

Note: AMR — antimicrobial resistance, AR—antibiotic resistance, ARB/ARG—antibiotic-resistant bacteria/antibioticresistant genes, CW—constructed wetlands, WWTP—-wastewater treatment plants, NTS—natural treatment system.

\subsection{Bibliography Approach and Analysis}

Previous literature was studied with a focus on papers describing measures of antibiotic resistance (including ARBs and ARGs) in CWs, WWTPs, wastewater, treated effluent, sludge, anaerobic digestion and activated sludge units of treatment plants, cattle feedlots and slaughterhouses [63]. A brief schematic in Supplementary Figure S2 demonstrates the basic steps conducted for the present review.

\section{Review Findings}

The present study is a literature review of studies related to antibiotic resistance in CW and WWTPs and its effluent discharge to water compartment, which is a major challenge in developing/less developed countries. Journal articles were identified in Scopus $(n=65)$, Web of Science $(n=55)$, Science Direct $(n=33)$, Google Scholar $(n=15)$ and also scanned references $(n=31)$. The total number of journals articles screened for the present review was 199. This included publications related to WWTPs (74), CWs (59), rural and urban wastewater (28), hospital wastewater (12), and aquatic and soil ecosystems (26). We then framed the question of concern regarding the protocols for antibiotic resistance, restrictive use of antibiotics, treatment of wastewater, effluent discharges and use and implementation of natural treatment system for ARG/ARB removal with a focus on ARGs 
in wastewater. Hotspots of antibiotic resistance in the environment and their pathway of exposure/disposal were identified. The recent studies were subdivided into (i) clinical studies based on case studies reported in humans, plants and animals, and (ii) environmental studies based on lab and field studies on water, soil, agricultural farms, poultry and anthropogenic activities. Then, information pertaining to the performance efficiency of WWTPs and CWs for the elimination of antibiotic resistance was consolidated. There is an increasingly robust body of literature on CWs and their potential technology that assists in the removal of antibiotic resistance. Studies reported during 2019 and 2021 demonstrate encouraging use of CWs for the reduction of general water and microbial pollutants. It is expected that the application of CWs may further increase in the near future due to its multiple benefits such as aesthetics, ability to reduce a variety of pollutants, and capacity for different configurations to suit stakeholders' requirements.

\subsection{Main Drivers of Antibiotic Resistance in Wastewater}

Antibiotic drugs are considered the main driver of antibiotic resistance, and they enter the wastewater stream via human, animal, medical, and industrial waste, along with heavy metals of different concentrations according to their sources. The sublethal concentration of antibiotics/heavy metals/biocides may alter/have a direct impact on microbial cell function as well as resistance properties [64]. These waste streams also contain enteric pathogens, coliforms, phages, ARB, and ARG, which then are combined during centralized waste treatment. All are routinely isolated from WWTP [65,66], which are considered hotspots of horizontal gene transfer of ARGs [9]. CWs are an alternative system for treating these waste streams, and there is a growing body of work exploring the occurrence, persistence, and reduction of antibiotic drugs, ARB and ARG in CW. There is a suite of drug-resistance types and bacteria that are a top priority for human health and environmental surveillance of antibiotic resistance. For example, Enterococci species are associated with feces and species such as Enterococcus faecium and Enterococcus faecalis have been linked to illnesses such as urinary tract infections and endocarditis [67]. Enterococci possess an intrinsic ability to resist a wide spectrum of antibiotics, including cephalosporins and aminoglycosides [68]. They also have a natural tendency to acquire and disseminate antibiotic resistance against a variety of antibiotics [69]. Escherichia coli that cause infections are generally more resistant than commonly found E. coli associated with fecal matter. Hence it is only possible to predict clinical resistance from wastewater analysis if the difference in resistance level between both strains (E. coli strains that cause infections and strains that are associated with fecal contamination) causing infections is more or less the same [70].

\subsection{Efficiency of Conventional Treatment Plants for Reduction of Antibiotics, ARBs and ARGs}

WWTPs are generally comprised of preliminary and primary treatment (screening and sedimentation basin) for the removal of suspended solids. The secondary treatment includes an activated sludge process and a biological contactor/filter process responsible for degrading/breaking organic compounds assisted by microbial metabolism. The tertiary treatment includes disinfection, CWs, sand filtration, a membrane bioreactor, etc. The treatment technology and use of tertiary treatment methods impact the prevalence of antibiotics, ARBs and ARGs.

\subsubsection{WWTPs and Antibiotic Reduction}

Antibiotics are chemical pollutants and include drugs such as $\beta$-lactams, cephalosporins, fluoroquinolones, tetracyclines and sulfonamides, among others. They find their path to the WWTP from domestic, industrial, clinical, pharmaceutical and other effluent discharges [64,71,72]. Each type of antibiotic drug possesses different physicochemical properties that impact its adsorption and biodegradation process during wastewater treatment. In conventional WWTP, hydrophobic antibiotics like chloramphenicol and aminoglycosides [73] will get adsorbed onto the sludge, whereas hydrophilic antibiotics such as 
fluoroquinolones will be removed through electrostatic interactions with the cell membrane of microorganisms [74]. The authors of [75] investigated the incomplete removal of fluoroquinolones by WWTPs comprised of a conventional activated sludge process and membrane bioreactor. Maximum removal was observed in the range of $2-31 \%$. In contrast, sulfamethoxazole was removed in the range of $4-56 \%$, with maximum removal reported in a membrane bioreactor. Sulfonamides are insoluble in water. Less absorptive sulfonamides are mostly degraded in the oxic tank [76]. They are generally removed from the water phase by biodegradation and photodegradation. Trimethoprim is primarily removed by sediment adsorption [77]. The quinolone molecule is also strongly adsorptive and is soluble in water in the same manner as aminoglycosides. WWTPs have been shown to be effective in the removal of tetracyclines due to their hydrophilic nature [78]. Most tetracyclines that enter the system get adsorbed by activated sludge flocs, concentrated, and removed mainly by the secondary clarifier. The presence of certain nitrifying and oxidizing bacteria (Actinobacteria, Proteobacteria, Nitrospirae) in the activated sludge component of WWTP assists in the biodegradation of antibiotics [4], including Dechloromonas and Thauera, that have been identified as typical denitrifying bacteria in wastewater treatment [79]. Various studies have reported the removal of antibiotics with an advanced oxidation process [80,81]. Reverse osmosis and activated carbon (used for tertiary treatment) do not degrade or remove but transfer the antibiotics from one phase to another. However, the use of $\mathrm{TiO}_{2}$, $\mathrm{ZnO}$, and $\mathrm{CdS}$ for photocatalysis has shown encouraging results for antibiotic removal due to their availability, nontoxic nature, low cost, strong oxidizing capability and use either as colloids or in an immobilized form [82].

\section{Primary Treatment Data/Literature}

Various works of literature have reported that primary treatment is ineffective for the removal of antibiotics with a low reduction of antibiotic residues [83]. Complexities exist in WWTPs where biodegradation, hydrolysis, and adsorption to sludge are the significant processes that assist in the elimination of antibiotics.

\section{Secondary Treatment Data/Literature}

Investigations report that the removal efficiency of a particular antibiotic varies significantly even within the same type of process, such as activated sludge or anoxic/oxic (A/O) conditions. The use of only activated sludge may not show better results as compared to a combination of activated sludge with anoxic and oxic conditions. Therefore, a hybrid system employing both enhances the removal of antibiotics such as lincomycin in the range of $58-74 \%$ [84]. It is a challenge to detect trace levels of antibiotics in the wastewater of WWTPs, where several factors such as $\mathrm{pH}$, matrix interferences and other environmental factors (solar irradiation, temperature and precipitation) result in inaccurate detection. In a study reported by [85], the removal of antibiotics was investigated, considering the various operational parameters. They found that the removal of clindamycin and ciprofloxacin has a significant correlation with temperature and sludge retention time. Reduction of fluoroquinolones has been reported to be reduced $>80 \%$ in WWTPs that employ activated sludge treatment methods [86], where the activated sludge treatment involves the biodegradation of antibiotics [87].

\section{Tertiary Treatment Data/Literature}

Tertiary treatment involves disinfection methods that assist in the removal of microbial contaminants and often involve chlorination. They are also found to be efficient for the removal of tetracycline, trimethoprim, erythromycin, ciprofloxacin, sulfamethoxazole and norfloxacin. As reported by [88], when comparing tertiary with secondary treatment, the antibiotic concentration is significantly reduced in the former with approximately $3 \%$ for tetracycline, $5 \%$ for norfloxacin, $11 \%$ for both sulfamethoxazole and ciprofloxacin, $17 \%$ for erythromycin and $23 \%$ for trimethoprim. Removal of approximately $93 \%$ [89] to a maximum of 99\% [90] of trimethoprim has been reported, indicating good efficiency of 
tertiary units employing chlorination alone for the elimination of this particular antibiotic. A recent study has also reported the elimination of tetracycline, sulfonamides and macrolides by chlorination [91]. UV treatment, however, has not been considered efficient for the removal of antibiotics. About $15 \%$ removal of antibiotics is observed in UV, as compared to $45 \%$ removal in chlorination treatment as reported by [92]. Other treatment processes such as ozonation are quite expensive but effective at removing antibiotics. The authors of [93] have reported removal of antibiotics in the range of $40 \%$ to $80 \%$ with $\mathrm{O}_{3}$ treatment. In this process, the antibiotics are oxidized by $\mathrm{O}_{3}$ molecules or hydroxyl radicles after $\mathrm{O}_{3}$ decomposition [94]. Employing sand filter units alone does not effectively reduce the concentration of antibiotics, as the hydrophilic nature of most antibiotics means they remain suspended in the liquid phase. The exception is the removal of sulfamethoxazole with reduction rates in the range of $34 \%$ to $95 \%$ in sand filters $[95,96]$. They can be used in combination with other tertiary methods to improve performance. There is significant variation of antibiotic removal efficacy in WWTPs, indicating that the removal depends not only on the wastewater matrix but also on seasonal variations along with physicochemical properties of the antibiotics. Other factors such as degradation rates in the water, the acid dissociation constant, water solubility, and organic carbon water partition coefficients also assist in the removal from WWTPs [81]. The high removal rate of certain antibiotics such as quinolones is due to their adsorption into the sewage sludge, with a high sorption constant [97]. It has been proposed that complete removal of antibiotics is not possible in conventional WWTPs, and concerns remain about the discharged effluents being a threat to aquatic ecosystems and human health. Therefore, advanced technologies employing adsorption [98], advanced oxidation processes, such as Fenton-like oxidation [99], ozonation [100], sulfate radical-based oxidation [101], and ionizing radiation [102,103] are being recently used for the elimination of antibiotic residues.

\subsubsection{WWTPs and ARB Reduction}

ARBs such as antibiotic-resistant E. coli and Enterococci are present in raw sewage and final treated effluent in WWTPs. These bacteria can display a range of antibiotic resistance phenotypes, and hence their removal in WWTP is of importance. The authors of [104] investigated both E. coli and Enterococci isolated from wastewater and found between $0.7-100 \%$ of the isolates in that study displayed at least one resistance phenotype. They also determined that bacterial species that are resistant to more than three antibiotics were about $25 \%$ in the influent and less than $20 \%$ in wastewater that was subjected to chlorination. A different study reported that the effluent of a WWTP consists of approximately $9.9 \%$ resistant E. coli and $0.2 \%$ total resistant coliforms. Based on previous reports, a two-log reduction of E. coli and Enterococci in WWTP is possible [105,106], including a 2 to 5 log reduction of resistant bacteria $[107,108]$.

\section{Primary Treatment Data/Literature}

There is a diverse community of ARBs present in the influent of WWTPs, including untreated wastewater and hospital wastewater, providing evidence for the presence of clinically relevant ARBs. In particular, there is a lack of studies reporting the reduction of ARBs in primary units. Though selective pressure due to the presence of heavy metals, antibiotic residues, and other pollutants has the potential to assist in the amplification and spread of ARBs to the receiving environment, appropriate technology can reduce or eliminate them in the final effluent. Physical processes such as primary screening, grit removal and sedimentation remove the majority of the suspended solids, along with adhered bacteria. Primary screening does not remove/eliminate any suspended ARBs, as the screens are used for removing larger floating materials in the wastewater. Sedimentation also does not support significant removal of ARBs, as reported by $[109,110]$. However, a reduction in the range of $0-1$ logs, as indicated by [111], has been reported. The removal of pathogens and ARBs is usually not high in primary treatment; therefore, it is important that downstream treatment units should efficiently remove ARB to avoid health risks. 
Secondary Treatment Data/Literature

Teshome [112] has investigated activated sludge systems, showing they perform better as compared to septic tank systems for the removal of bacteria. The load of total and fecal coliforms, Enterococci species and $E$. coli in the raw influent was reported to be approximately $5.14 \times 10^{8}, 2.45 \times 10^{7}, 1.31 \times 10^{8}$, and $1.17 \times 10^{7} \mathrm{cfu} / 100 \mathrm{~mL}$, respectively. Following activated sludge treatment, these numbers were reduced to $3.18 \times 10^{5}, 5.12 \times 10^{4}, 3.93 \times 10^{5}$, and $2.75 \times 10^{4} \mathrm{cfu} / 100 \mathrm{~mL}$, with a $\log$ reduction of $3.21,2.68,2.52$ and 2.62 , respectively. This was comparable with the log reduction obtained after treatment with a septic tank system that ranged between 1.33 to $1.59 \mathrm{cfu} / 100 \mathrm{~mL}$. The study also indicated that although there was a reduction of the bacterial population, there was an increase in the multidrug-resistant profiles of the isolates during wastewater treatment. It can be inferred that WWTP do provide a suitable environment for the proliferation of ARBs containing a high proportion of resistant bacteria. Berrios-Hernandez [113] inferred that the removal of fecal indicator organisms is not correlated to water quality parameters but is generally dependent upon the treatment technology used. In the case of E. coli, total suspended solids have been positively correlated with its removal, supporting the efficacy of primary and secondary treatment units for the removal of the microbial population. Activated sludge and novel aerobic granular sludge demonstrated somewhat similar removal efficiencies.

\section{Tertiary Treatment Data/Literature}

The relationship between chlorination and antibiotic resistance is complex. Disinfection in WWTPs includes the use of chlorine, UV irradiation and ozone. Chlorine is widely used in WWTPs due to its cost-effective nature and its beneficial oxidizing capacity for reducing the microbial population and pathogens in wastewater [114]. Chlorination used for tertiary treatment results in inactivation of bacterial cells and reduction of bacterial numbers, as measured by both culture and 16S rRNA [115]. Generally, chlorination, as currently used in tertiary treatment, induces the development of antibiotic resistance and co-selection of ARBs due to intermediate disinfection by-products (DBP), as reported by [116], or by inducing expression of multidrug efflux pumps. However, studies have reported that a fixed contact time (CT) value for a short duration of time combined with a high concentration of applied chlorine can decrease the abundance and reactivation of ARBs [117]. In contrast, longer CT combined with low chlorine concentrations may contribute to accelerated reactivation and regrowth of ARBs [118]. Other factors that contribute to the persistence of ARBs in WWTPs include a positive correlation with suspended solids and the chemical oxygen demand (COD) of untreated wastewater and a negative correlation with the temperature and dissolved oxygen (DO) of the effluent [119]. Several other factors, such as the type of antibiotic resistance, increase in ARBs due to the type of raw influent and environment of WWTPs, and decrease in antibiotic-sensitive bacteria in the bacterial population of the treated effluent, impacts the proportion of ARBs [120] and contributes to ARB load in WWTP. Antibiotic-resistant strains are frequently reported in the effluent, for example, E. coli, C. perfringens, fecal enterococci and Sphingomonas by [121], or ampicillin-resistant and tetracycline-resistant E. coli along with chloramphenicol- and cephalothin-resistant bacteria [122]. The authors of [115] identified E. coli, Citrobacter and Enterococcus for their survivability at $0.5 \mathrm{mg} / \mathrm{L}$ of free chlorine concentration. Bacterial cells that survive chlorination can re-grow and remain a concern for public health $[123,124]$. UV has been found to be beneficial for the reduction of ARBs [125] and their genes [126]. UV radiation acts directly on the DNA of microbes and does not react with ammonia or residual chlorine of treated wastewater. A recent study conducted by [1] reports reductions of 1-3 logs in facultative pathogenic bacteria after conventional wastewater treatment with UV. The major disadvantages of UV are that it is not a continuous process, as it provides time for photo-reactivation after the disinfection process. It also requires a high dose to eliminate ARBs, which is not practical in the applied field settings.

Ozonation has also been shown to impact the removal of ARBs by inactivation of bacterial populations (including antibiotic-resistant bacteria) due to the production of 
highly reactive radicles, though it is generally employed for the removal of organic micropollutants [127]. Additionally, ozonation followed by a filter passage can further lead to the reduction of total coliforms, E. coli, Staphylococcus and Enterococcus in the range of 0.8 to $1.1 \log$ units when compared to flocculation filtration. Enterobacteria, Staphylococcus, Enterococci, and $P$. aurigonosa have demonstrated varying removal rates in the range of $60.2 \%$ to $98.9 \%$ at a concentration of $0.9 \pm 0.1 \mathrm{~g} \mathrm{O}_{3}$ DOC-1 (dissolved organic carbon), which is considered a regular dose applied for ozonation [128]. A log reduction in the range of 2.7-3.7 units has been reported with an ozone concentration that varies in the range of $5 \mathrm{mg} / \mathrm{L}$ to $10 \mathrm{mg} / \mathrm{L}$ for E. coli present in WWTP [129]. A high concentration of ozone in the range of $25-30 \mathrm{mg} / \mathrm{L}$ can reduce coliforms by $4.4 \mathrm{log}$ units, Enterococci by approximately $3.6 \log$ units and Clostridia in the range of 1.2-1.7 log units [130]. The resistances of the target microbes, the degree of damage due to ozonation, and the quality of wastewater are some of the factors that assist in the further reduction of ARBs in ozonation treatment. Combinations of different units are effective for reduction in abundance for Pseudomonas, Enterococcus and E. coli $[131,132]$. The conventional treatment of wastewater that includes removal of solids, sediments, grease, sludge [133], biological removal of nutrients such as nitrates and phosphates [134] along with tertiary treatment for disinfection [135], use of CWs [136], advanced oxidation process (AOP) [137] and hybrid units are efficient for the elimination of a large number of ARBs [138]. There remain many knowledge gaps on the regrowth and reactivation of ARBs after conventional treatment.

\subsubsection{WWTPs and ARG Reduction}

WWTPs provide suitable temperature, $\mathrm{pH}$, nutrients, and environment for the growth and proliferation of bacteria, transfer of ARGs, and spread of both to the receiving water bodies or soil [138]. Generally, it has been found that the concentration of ARGs in influent and effluent vary according to treatment technology. Bacteria carrying multidrug resistance and ESBL genes such as E. coli, Enterobacter species, and Salmonella species can be detected in treated effluent. The ARGs code for resistances associated with health risk threats and are especially concerning when associated with pathogens. The impact of WWTP-associated ARGs on environmental bacteria is unknown but is of potential concern.

Primary Treatment Data/Literature

As reported by [139], a negligible amount of ARGs are removed after the reduction of suspended solids in primary treatment. It may range between 0.09 and 0.55 orders of magnitude [140] and also, as reported by [141], in the range of 0.17 to 0.5 logs. The sedimentable solids generated that settle in primary settling tanks contain ARGs, which may enter the environment if the solids are used as fertilizer without any sludge treatment, such as the application of lime. ARGs and their host bacteria may be recirculated along with the sludge (used for seeding purposes) into the WWTP system, further increasing ARG abundance in the treatment plant [142].

Secondary Treatment Data/Literature

Reports of ARG removal efficacy after secondary treatment are mixed and depend on a complex interaction of factors. Some reports have confirmed 1-2 log reductions of ARGs [143], while others report 1.3-6.1 log reduction of ARGs [107,119,144]. Higher rates of reduction have been observed due to the removal of suspended solids (in primary treatment) and activated sludge processes (in secondary treatment) [139]. Stiborova [145] concluded that dewatered activated sludge promotes the development of multidrug resistance due to adsorption on its solid surface, acting as a reservoir of ARGs when used as fertilizer in agricultural soils.

Tertiary Treatment Data/Literature

Tertiary treatment plays a significant role in lowering the abundance of ARGs. A recent study by [146] reported the reduction of total 16s rRNA, ARGs and int 1 by $0.1 \pm 0.4$ 
$\log 10$ copies $/ \mathrm{mL}$, tet A by $0.9 \pm 0.6 \log 10$ copies $/ \mathrm{mL}$, erm F by approximately $0.1 \pm 0.3$ $\log 10$ copies $/ \mathrm{mL}$, blaTEM by $0.4 \pm 0.5 \log 10$ copies $/ \mathrm{mL}$, and int 1 by $0.5 \pm 0.4 \log$ 10 copies $/ \mathrm{mL}$. They reported the same type of variation in another treatment plant, indicating a reduction in the abundance of ARGs. The final effluent of 2 WWTP released $3.3 \pm 1.5$ $\log 10$ copies $/ \mathrm{mL}$ and $3.4 \pm 1.4 \log 10$ copies $/ \mathrm{mL}$ of total ARGs and int 1 . Therefore, their results demonstrate that the conventional WWTPs using chlorination can be confidently used to avoid the proliferation of ARGs during treatment. ARGs are naturally carried within bacterial host cells, either chromosomally or on plasmids. Upon lysis of the host bacteria, ARGs are released into the environment where they persist until they are taken up by a new host or are degraded and lose their biological activity. However, even when chlorine and other disinfectants kill bacteria, they do not necessarily inactivate or degrade the ARGs [147]. While effective for reducing viability in bacteria, cells that survive chlorine treatment appear to be primed to uptake foreign genes, including ARGs released from recently killed bacteria [148]. The hydroxyl radical and reactive chlorine species formed result in DNA damage and may also alter the genetic characteristics [149].

High CT favors the reduction of ARGs when they are present at high concentrations but is less effective when ARG targets are present in lower concentrations. For example, some evidence suggests that certain ARGs may be more easily inactivated by high CT (>80 $\mathrm{mg} \mathrm{Cl}_{2}$ min $\mathrm{L}^{-1}$ ) as compared to low CT ( $<10 \mathrm{mg} \mathrm{Cl}_{2} \mathrm{~min} \mathrm{~L}^{-1}$ ) than others [150], though it is not clear yet what other factors may impact these results. ARG removal can be observed beyond the breakpoint of chlorination [151] with an added advantage of oxidizing organic matter and removing color and odor from wastewater. In contrast, a study by [122] revealed that $80 \%$ and $40 \%$ of tetracycline- and erythromycin-resistant genes, respectively, could not be removed even after chlorination with a CT value of $15 \mathrm{mg} \mathrm{Cl} / \mathrm{min} / \mathrm{L}$ (average range is $15-30 \mathrm{mg} \mathrm{Cl}_{2} / \mathrm{min} / \mathrm{L}$ with different $\mathrm{CT}$, which is quite efficient for reduction of ARGs in wastewater). The residual chlorine in the effluent reactivates the development of ARGs [152]. It also promotes HGT and alters the permeability of bacterial cells [153]. Zhang [117] reported the maximum removal of ARGs to be up to a $1.49 \log 10$ reduction, which was obtained with a free chlorine dose of about $30 \mathrm{mg} / \mathrm{L}$ and $30 \mathrm{~min}$ contact time.

Proper dosing of chlorine with CT (and focusing on by-products obtained) coupled with natural treatment systems (such as CWs, where nutrients and various pollutants present in wastewater are broken down/degraded naturally and taken up by plants and bacterial communities, removing them from wastewater) prevents the growth of pathogenic bacteria and is a useful option for effluent to be discharged to the environmental matrix $[154,155]$. Moreover, while considering the role of tertiary treatment in the removal of ARGs, their dose of application $\left(\mathrm{O}_{3}, \mathrm{UV}\right.$ and chlorine), contact time with the wastewater and wastewater characteristics play a significant role $[4,65,156]$. Additionally, investigations have reported that there are times when $\mathrm{O}_{3}$ is relatively less effective than the other two disinfection methods, as $\mathrm{O}_{3}$ gets generally consumed by the organic matter in the effluent [157]. When coupled with UV treatment, chlorination is reported to be modestly effective for the removal of ARG, integrons that are associated with horizontal gene transfer, and 16s rRNA genes that serve as a marker for bacterial cells [158]. Despite the fact that ARGs can persist following tertiary treatments, disinfection methods have been shown to be successful for the reduction of ARGs. There are multiple factors that allow for the reduction of ARGs in tertiary treatment. The type and process used for wastewater treatment, location specifics, seasonal influence, the concentration of ARGs already present in the influent, the concentration and type of antibiotics and other contaminants in the influent, and survival factors of the host bacterial taxa all impact the efficacy of tertiary treatment for the reduction of ARGs. Other factors that impact ARG removal are initial ARG concentration and water quality, especially the concentration of ammonia nitrogen in wastewater (>15 mg/L), with a reduction of approximately $1.49 \log 10$ ARG [146]. Furthermore, appropriate pre-treatment of sludge with free ammonia is able to enhance anaerobic digestion, as reported by [159]. Figure 2 consolidates the efficiency of removing antibiotics and resistant genes by conventional and tertiary treatment technologies, including CWs. 


\begin{tabular}{|c|c|c|c|c|c|}
\hline & Process/technology involved & & AB removal \% & ARBs removal \% & ARGs removal \% \\
\hline tre & - Screens \& Sedimentation & & Negligible reduction & $0-1$ logs & $0.09-0.55$ logs \\
\hline $\begin{array}{l}\text { Secondary } \\
\text { treatment }\end{array}$ & $\begin{array}{ll}\text { - } & \text { Biofilm process } \\
\text { Activated sludge (AS) - } \\
\text { secondary sedimentation }\end{array}$ & $\begin{array}{l}\text { Sludge } \\
\text { processing }\end{array}$ & $\begin{array}{l}\text { AS - } 2->80 \% \text { (fluoroquinolones) } \\
93-99 \% \text { (trimethoprim) } \\
58-74 \% \text { (lincomycin) }\end{array}$ & $\begin{array}{l}\text { TC- } 3.21 \text { logs } \\
\text { FC- } 2.68 \text { logs } \\
\text { Enterococci sp. }-2.52 \text { logs } \\
\text { E.coli }-2.62 \text { logs } \\
\end{array}$ & $\begin{array}{l}\text { As - } \\
\text { : } 1-2 \text { logs } \\
\text { - } 2.4-4.6 \text { logs }\end{array}$ \\
\hline $\begin{array}{c}\text { Tertiary } \\
\text { treatment }\end{array}$ & $\begin{array}{l}\text { Physical separation technologies } \\
\text { Chemical based approach } \\
\text { - Ozonation }\left(\mathrm{O}_{3}\right) \\
\text { - Ultraviolet radiation (UV) } \\
\text { - Chlorination } \\
\text { - Advanced oxidation process } \\
\text { (AOP) }\end{array}$ & Water & $\begin{array}{l}O_{3}-40-80 \% \text { (for different AB) } \\
\text { UV - about 15\% (for different AB) } \\
\text { Chlorination- } \\
\text { - } 93-99 \% \text { (trimethoprim) } \\
\text { - } \sim 11 \% \text { (sulfamethoxazole) } \\
\text { - } \sim 17 \% \text { (erythromycin) } \\
\text { - } \sim 5 \% \text { (norfloxacin) } \\
\text { AOP - 95\% (penicillin), 90\% } \\
\text { (piperacillin), >99\% (difloxacin) } \\
\text { MBR - } \\
\text { - } 4-56 \% \text { (sulfamethoxazole) } \\
\text { - >70\% (trimethoprim, } \\
\text { lincomycin) } \\
\text { VFCW - } \\
\text { - } 26-84 \% \text { (sulfonamides) } \\
\text { - } 83-93 \% \text { (ciprofloxacin) } \\
\text { - } 89-100 \% \text { (trimethoprim) } \\
\text { HFCW - } \\
\text { - } 100 \% \text { (erythromycin) } \\
\text { - } 76 \% \text { (norfloxacin) } \\
\text { - } 69 \% \text { (sulfapyridine) } \\
\text { - } 64 \% \text { (ofloxacin) } \\
\text { IFCW - } ~ \\
\text { - } 75 \% \text { (tetracycline) } \\
\text { - } 78-100 \% \text { (sulfamethazine, } \\
\text { lincomycin, ofloxacin, } \\
\text { leucomycin) } \\
\text { SAT - } 34-95 \% \text { (sulfamethoxazole) }\end{array}$ & 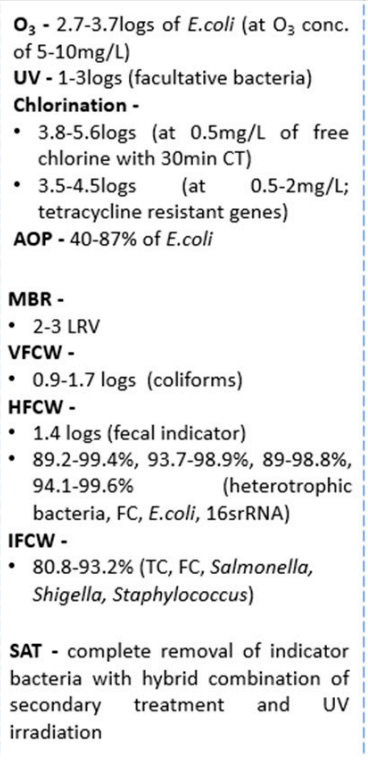 & 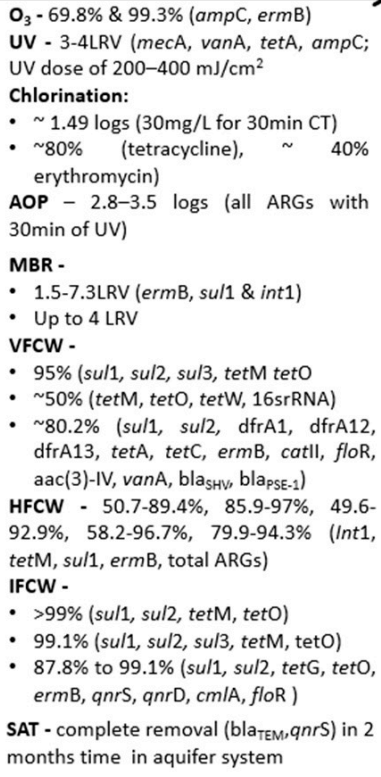 \\
\hline
\end{tabular}

Figure 2. Removal of antibiotics, antibiotic-resistant bacteria and genes by conventional and tertiary treatment technology, including constructed wetlands (Note: VFCW-vertical flow CW, HFCWhorizontal flow $\mathrm{CW}$, IFCW-integrated flow $\mathrm{CW}$ ).

\subsection{Performance of CW for Elimination of Antibiotics, Antibiotic-Resistant Bacteria and Genes}

There is an emerging awareness of the value provided by biological treatment processes employing CWs $[160,161]$. CWs have a long history of being utilized for pollutant removal, and research has shown them to be capable of significant reductions of organic pollutants, nutrients [162], heavy metals [163,164], antibiotics, and emergent contaminants such as ARG/ARB [32,165]. They can be configured in many ways and tailored to meet individual needs and specifications. Supplementary Table S1 consolidates the comparative techno-economic assessment of CWs over other technologies.

\subsubsection{Efficiency of CWs for Removal of Antibiotics}

Antibiotic drug residues are released to the environment through WWTP and can affect the efficiency of the microbial communities essential to $\mathrm{CW}$ function. Antibiotics inhibit some types of bacterial growth [166], impact denitrifying bacteria $[167,168]$ and potentially alter the denitrification rate [169]. Remediation of wastewater containing a high percentage of nitrate utilizes biological denitrification, where $\mathrm{CW}$ plays a significant role [170]. Other important CW functions that rely on microbial processes are the removal of organic carbon (the soluble labile forms present in primary treated domestic wastewater), the removal of pollutants such as heavy metals, and the removal of total nitrogen [171]. The reduction of sulfate also plays a significant role in metal removal, and hence, sulfide oxidation is an important process in CWs. Pollutant removal and microbial activity in CWs are closely associated with nitrogen, sulphur and carbon cycling [171]. Considering the introduction of antibiotics to CWs, for example, the presence of ciprofloxacin in wastewater influent leads to an increase in resistance for other classes of antibiotics such as penicillins, tetracyclines, sulfonamides, and cephalosporins, including ciprofloxacin. Antibiotics have the potential of increasing the antibiotic resistance profile of others present [172]. Studies by [173] evaluated the high concentration of erythromycin and sulfamethoxazole in the 
influent of CW. They reported microbial degradation plays a significant role in the reduction of these drugs (13-99\%) from wastewater.

A growing body of work exists examining the efficiency of various CW systems to remove individual antibiotic drug targets. One theme that emerges from the work done to date is that the diversity of $\mathrm{CW}$ configurations, process parameters, and site-specific differences can impact drug removal efficiency. Li [174] evaluated the removal of tetracycline in an integrated VFCW with three days of hydraulic retention time (HRT) and continuous flow of domestic wastewater and reported up to $75 \%$ removal efficiency, similar to earlier reports by [83]. Tetracycline and quinolones are less soluble and possess a greater tendency to get adsorbed to substrates, where they undergo photodegradation due to solar influx. VFCWs have also been reported to reduce sulfamethazine, sulfadiazine and sulfamethoxazole in wastewater, with removal efficiencies in the range of $26.42-84.05 \%$ [175]. Nitrification was slightly enhanced due to the presence of sulfamethoxazole. It was confirmed that both aerobic and anaerobic microbial degradation assists in the removal of sulfonamides from VFCWs. Sulfonamides did not influence total phosphorus (TP), total organic carbon (TOC), or ammonia-nitrogen $\left(\mathrm{NH}_{4}{ }^{+}-\mathrm{N}\right)$ removal but increased the diversity and altered the community structure of bacteria. It is indicated that the antibiotics induce selective pressure on the bacterial population, rendering them resistant to a wide range of antibiotics.

Vertical subsurface flow CWs (VSSFCW) are basically operated by providing intermittent feeding (of wastewater) from the top that drains to the bottom of a filter bed. The intermittent flow allows the process of nitrification in the unsaturated zone, promoting microbial degradation of antibiotics in a way that is superior as compared to HSSF-CW, which remains saturated all through [176]. Hence, these unsaturated phases between pulses allow an enhanced nitrification capacity for the removal of $\mathrm{NH}_{4}-\mathrm{N}$ and organic matter [177]. The denitrification process is generally limited due to the lack of an anaerobic area that is required for the growth of denitrifying bacteria. The microbial communities in the VSSFCW allow complete nitrogen transformation through nitrification/denitrification, as the microbes are metabolically active and play a significant role accordingly. Reports by [178] highlighted that microbial degradation was responsible for the up to $94 \%$ reduction observed for tetracycline and enrofloxacin. The partial saturation in the lower zone of the media (that is comprised of gravel or other media) promoted redox gradients throughout the filter beds [179]. Benefits of VSSFCWs include higher removal of pollutants, especially emergent contaminants such as antibiotics (sulfamethoxazole, erythromycin, trimethoprim, etc.) and ARGs [180] compared to standard WWTPs. Liu [181] have evaluated $106 \mathrm{CW}$ and measured their removal of 39 classes of antibiotics as well as antibiotic resistance genes. It was found that VSSFCWs were the most efficient of all the configurations and showed an average removal of $70 \%$ of the antibiotics. The VSSF had different ranges of operating parameters, including temperature, solar flux, type of influent, and concentration of antibiotic residues. Physical characteristics such as water solubility and octanol-water distribution coefficient (Kow) of the antibiotic compounds affect its removal from CW. A study [182] working in a VFCW system reported the removal of ciprofloxacin in the range of $83-93 \%$ and sulfamethazine in the range of $56-69 \%$. Liu [181] demonstrated an $81 \%$ reduction in macrolide concentration in a VSSF-CW. The mechanism was thought to be a combination of high Kow values, less water solubility and high adsorption of the drug onto the substrate and plant roots. These results highlight the complexity of antibiotics in the environment and the urgent need to identify which measurements are most relevant for assessing risk to human, animal, and environmental health.

Sochachi [183] evaluated removal of sulfamethoxazole in the range of 52.8-91.2\%, where the VFCWs were planted with reed canary grass 'Picta' (Phalaris arundinacea L. var. picta $\mathrm{L}$ ) that was used for the treatment of urban wastewater. It was observed that the presence of antibiotics or pharmaceuticals and their transformation products had a direct impact on the floating plants and resulted in deterioration and decay, thereby showing phytotoxic activity. It was also concluded that despite high concentrations of antibiotics/pharmaceutical, the emergent macrophytic species, namely Gaint Miscanthus, in 
subsurface flow constructed wetlands (SSFCW) demonstrated no alterations in their physical appearance and suggested the use of hybrid systems for SSFCW and SFCW. Integrated flow constructed wetlands (IFCW) use a combination of different CW. IFCWs demonstrate better efficiency compared to a single unit of CW mainly for the removal of nutrients and other pollutants [184]. Choi [185] investigated Pharagmites australis and Triarrhena sacchariflora, which were found to efficiently remove sulfadiazine at rates up to $81.86 \%$, sulfamethoxazole at rates up to $85 \%$, sulfamethazine at rates up to $49.43 \%$ and trimethoprim at rates up to $2.32 \%$ with a retention time of $48 \mathrm{~h}$. Chrysopogon zizanioides has also been used to remove antibiotics, especially tetracycline and ciprofloxacin, from secondary wastewater effluent in the presence of a high concentration of nutrients (specifically $\mathrm{N}$ and $\mathrm{P}$ ). The removal percentage varied between $89-100 \%$ for tetracycline and $60-94 \%$ for ciprofloxacin, and there was an inverse relationship between nutrient concentration and antibiotic removal [186]. Lab-based studies have reported the significance of plant species associated with microbial communities in efficiently removing antibiotics. Kurade [187], in a batch study, selected Ipomea aquatic based on its potential for remediation of $100 \%$ sulfamethoxazole in $30 \mathrm{~h}$. It was observed that the primary mechanism of sulfamethoxazole elimination was biodegradation, which accounted for $82 \%$ of the observed reduction. Results demonstrated that Ipomea converted sulfamethoxazole into simple compounds like 4-aminophenol as its end product. Plant roots assisted in bioadsorption but accounted for only $0.77 \%$ of the drug removal, and leaves bioaccumulated up to $16.94 \%$ of the sulfamethoxazole. An $8 \%$ increase in chlorophyll and a 9\% decrease in carotenoids was observed after $48 \mathrm{~h}$ of exposure to sulfamethoxazole, but this did not induce any toxic effect on the photosynthetic activity of Ipomea. It has a defense mechanism against toxicants and abiotic stress which is activated during the initial exposure to sulfamethoxazole. In a different study, the efficiency of CW planted with Juncus acutus was utilized for the removal of ciprofloxacin at rates of up to $93.9 \%$, but no significant removal was observed for sulfamethoxazole [188]. Juncus acutus is a halophyte tolerant to different stressors, specifically organic xenobiotics, heavy metals, endocrine-disrupting chemicals, pharmaceuticals and personal care products. This makes it a particularly good candidate for CW. Only $2 \%$ of plant species (of the known plant species) are halophytes that demonstrate good phytoremedial potential [189-191]. Along with metal accumulation, phytostabilization has also been reported as another remediation mechanism in the root structure of J. acutus [188].

\subsubsection{Efficiency of CWs for Removal of ARBs and ARGs}

In addition to the ability to reduce the concentration of antibiotic drugs in wastewater systems, CWs have also been evaluated as a means to mitigate ARBs and ARGs. Figure 3 highlights, in brief, the protocols used for antibiotic resistance, factors associated to encourage this review study, along with the benefits and use of CWs. In this regard, the large body of work evaluating the efficacy of CWs to reduce fecal bacteria, including fecal pathogens, helps to inform our understanding of the potential of CWs for remediating antibiotic-resistant bacteria of both fecal and environmental origin. Previous studies have already reported the removal of pathogenic and fecal indicator bacteria in a variety of CW systems [192,193]. As with WWTP, positive correlations have been reported for CW between microbial parameters and $\mathrm{NH}_{4}$, total nitrogen $(\mathrm{TN})$, and a negative correlative between E. coli and total suspended solids (TSS), TP, COD and biochemical oxygen demand (BOD) [194]. Lamori [195] highlights that the E. coli concentration decreased up to $50 \%$ in the effluent of a CW as compared to the influent. In the study, they compared the presence of E. coli, Enterococci, Bacteriodales (HF183) and ARG (erm(F) and int1) in the influent and the treated effluent. It was demonstrated that $\operatorname{erm}(\mathrm{F})$ and int were reduced by $13 \%$ and $67.2 \%$. The study also found that there was no correlation between turbidity and ARG, though sediments act as a reservoir of ARGs. The growth of E. coli was affected by water temperature, sedimentation rate, pollution source and overall bacterial growth. At higher temperatures (especially during the summers), the reduction of E. coli (that was present in $100 \%$ of the water samples) ranged between 31 and $70 \%$ and Enterococci between 70 and 
$99 \%$. The temperature had an impact on microbial composition in treatment plants that affected bacterial removal rates. It was indicated that the microbes grow and survive at a $\mathrm{pH}$ range of 5.5-7.5 and are $\mathrm{pH}$-sensitive [196]. High $\mathrm{pH}$ was associated with increased bacterial/pathogen removal in CWs. The removal of pathogens also depends upon the physicochemical factors of wastewater [32] and the source of treated effluent. It is indicated that the overall bacteria decrease but are still abundant in the final effluent of a conventional treatment plant. CWs further reduce the concentration of bacteria due to vegetation, temperature, sunlight, high retention time, etc. Furthermore, as reported by [197], during winters, the removal rate of ARGs is considerably high as compared to summers, most probably due to low temperature.

Consolidation of information pertaining to performance efficacy of $\mathrm{CW}$ for removal of $\mathrm{AR}$ in India

\section{Protocols for AR}

- National Antimicrobial Resistance (AMR) action plan approved by Government

- Nationwide professional training on antibiotic resistance and antimicrobial use for veterinary sectors

- System designed for surveillance of antimicrobial use for monitoring national level sales and consumption of antibiotics in health services

- No national plan for monitoring sales/use of antimicrobials in animals or use of pesticides to check bacterial and fungal diseases

- National coordinating center for reports on AMR covering bacterial infections in hospitals and community patients

- Collection of AMR data locally; however, this is lacking national coordination and quality management

- National IPC programme is available but not fully implemented

- Guidelines for appropriate use of antimicrobials available

- National legislation covers aspects of manufacture, marketing, authorization, control of safety, quality, efficacy, distribution and import of antimicrobial products

Restriction of antibiotic use

- Statistics show overutilization of antibiotics and antimicrobials in India in recent years

- Target is to optimize the use of antibiotics and antimicrobials by human and animal purpose
Treatment of WW, sludge and discharge of effluents

- The functional WWTP discharge treated effluent to water bodies and soil

- Lack of tertiary treatment units and chlorination in treatment plants

- Sludge used as fertilizers without post treatment

- No standard for coliforms for the treated effluent, and directly discharged to water bodies and agricultural lands for irrigation
Use of natural treatment system

- CW have been implemented across India for reduction of pollutants, and coliforms

Eminent organizations and institutes like ICRISAT (Telangana), NEERI (Nagpur), Centre for Science and Environment (Delhi), Indian Institute of Technology (Mumbai), Aligarh Muslim University (Aligarh)

- Reduction of coliforms up to $99 \%$ have been evaluated and can be directly used for agricultural and aquacultural purpose. - They are being directly discharged to water bodies

Figure 3. Flow diagram representing, in brief, the protocols for antimicrobial resistance and benefits of using CWs in various organizations/institutes in India.

Hien [198] investigated the removal of five tetracycline-resistant genes (namely tet C, $\mathrm{M}, \mathrm{O}, \mathrm{Q}$ and $\mathrm{W}$ ) and reported their complete removal by a CW, with 1 day of retention time, using Pharagmites australis. The CW demonstrated a reduction of up to 3 logs for ARGs, which increased with an HRT of 2-3 days. A comparative work recently reported by [199] investigated the abundance of sulfonamide- and tetracycline-resistant genes in the influent and effluent of WWTPs with and without a CW. One WWTP using a conventional activated sludge (AS) system and a second WWTP coupling a CW with AS were evaluated for ARG removal potential. The $\mathrm{CW}$ was found to be more efficient for reducing $\mathrm{ARG}$ as compared to AS. Primarily, investigations have revealed that there exists a positive correlation between antibiotic concentration present in the influent and the abundance of resistant genes. One study reported a high concentration of ARG attributed to the accumulation of antibiotics in the bottom layer of the CW. Specifically, the sulI and tetracycline genes were found to be persistent due to the selective pressure by antimicrobial agents [200]. Multiple CW designs have been compared for their relative effectiveness in reducing ARB/ARG over time. SSFCWs were superior to SFCW for the elimination/removal of selected ARG targets [201]. In another study, however, they act as reservoirs for specific ARGs [197]. There was a 
strong positive correlation between the int1 gene and ARGs, suggesting that MGE affects the dissemination of ARGs in CW. The fate of ARGs sulI, sulII (sulfadiazine), tet M, tetO, tet $\mathrm{Q}$, tet $\mathrm{W}$ (from tetracycline) and $16 \mathrm{~S}$ rDNA genes was evaluated in a HSSF-CW. It was found that the HSSF-CW performed better than the conventional treatment plant with aerated filters or UV disinfection. The reduction of ARG was in the order of 1-3 log units after treatment [139]. Miller [202] has reported the efficiency of CW for the removal of ARGs, especially considering the HLR and HRT. In VSSF-CW, high infiltration and HLR lead to the filtering out of bacteria and help bind extracellular DNA onto the soil particles. A long duration of HRT allows the microbes to degrade the antibiotics, allowing ample time for the process to occur in the $\mathrm{CW}$ bed. Microbial degradation also depends on the seasons, where high temperatures allow better survival of bacterial populations. The VSSF CW showed an increase in ARG removal when substrates like zeolite were used, increasing the relative surface area and $\mathrm{Si}-\mathrm{OH}$ structures for chemical sorption along with degradation capacity of the microbes [203]. Table 2 consolidates a few recent studies highlighting CWs for the efficient reduction of ARB/ARG from various wastewater sources.

Table 2. Removal efficiency of various CWs for reduction of ARB and resistant genes.

\begin{tabular}{|c|c|c|c|c|}
\hline Type of CW & $\begin{array}{l}\text { Source/Type of } \\
\text { Wastewater }\end{array}$ & $\begin{array}{l}\text { Antibiotic-Resistant } \\
\text { Bacteria/Antibiotic-Resistant Genes }\end{array}$ & Removal Efficiency & References \\
\hline \multirow[t]{6}{*}{$\begin{array}{l}\text { Hybrid/integrated } \\
\text { flow CW }\end{array}$} & $\begin{array}{l}\text { Mixed wastewater } \\
\text { from restaurant, } \\
\text { hostel \& brewery }\end{array}$ & E. coli and thermotolerant coliforms & $99.5 \%$ & {$[204]$} \\
\hline & Dairy wastewater & $\begin{array}{l}\text { Total coliforms, fecal coliforms, fecal } \\
\text { streptococci, and E. coli }\end{array}$ & $99.93-99.99 \%$ & {$[205]$} \\
\hline & $\begin{array}{l}\text { Raw domestic } \\
\text { wastewater }\end{array}$ & sul2, erm B, cmlA and floR & $87.8 \%$ to $99.1 \%$ & {$[206]$} \\
\hline & Domestic wastewater & Enterococci, HF183, intI1, and ermF & $84.0 \%, 66.6 \%, 67.2 \% \& 13.1 \%$ & [195] \\
\hline & Raw landfill leachate & $\begin{array}{l}\text { Sulfonamide resistance (sul1, sul2, and dfrA), } \\
\text { aminoglycoside resistance (aac6), tetracycline } \\
\text { resistance }(\text { tet } \mathrm{O}) \text {, quinolone resistance }(q n r \mathrm{~A}) \text {, } \\
\text { and intl1, beta-lactam resistance (bla }{ }_{\mathrm{NDM} 1} \text {, } \\
\left.\text { bla }_{\mathrm{KPC}} \text {, and bla } \mathrm{CTX}\right) \text { and macrolide-lincosamide } \\
\text { resistance }(\text { erm } \mathrm{B})\end{array}$ & $>90 \%$ & [32] \\
\hline & $\begin{array}{l}\text { Rural domestic } \\
\text { wastewater }\end{array}$ & sul1, sul2, tet $\mathrm{M}$, and tet $\mathrm{O}$ & $>99 \%$ & {$[36]$} \\
\hline \multirow[t]{5}{*}{ Vertical flow CW } & Urban wastewater & sul1, sul2, qnrS, bla $\mathrm{TEM}_{\mathrm{M}}$ ermB & $\begin{array}{l}46-97 \%, 33-97 \%, 9-99 \% \\
18-97 \% \text { \& } 11-98 \%\end{array}$ & {$[41]$} \\
\hline & Swine wastewater & sul1, sul2, sul3, tetM and tetO & $95.1 \%$ & [207] \\
\hline & Swine wastewater & $\begin{array}{l}\text { Tetracycline-resistance genes (tet) and integrase } \\
\text { gene of Class } 1 \text { integrons }\end{array}$ & 33.2 to $99.1 \%$, & [208] \\
\hline & $\begin{array}{l}\text { Raw domestic } \\
\text { wastewater }\end{array}$ & $\begin{array}{l}\text { Sulfonamide resistance genes (sull, sul2 and } \\
\text { sul3), four tetracycline resistance genes (tet } \mathrm{G} \text {, } \\
\text { tet } \mathrm{M} \text {, tet } \mathrm{O} \text { and tet } \mathrm{X}) \text {, two macrolide resistance } \\
\text { genes (erm } \mathrm{B} \text { and } \mathrm{erm} \mathrm{C}) \text {, two chloramphenicol } \\
\text { resistance genes ( } \mathrm{cmlA} \text { and floR) and } 16 \mathrm{~S} \text { rRNA } \\
\text { (bacteria) }\end{array}$ & 63.9 and $84.0 \%$ & {$[203]$} \\
\hline & Swine wastewater & $\begin{array}{l}\text { Tetracycline resistance (tet) genes such as tet } \mathrm{M} \text {, } \\
\text { tet } \mathrm{O} \text {, and tet } \mathrm{W}\end{array}$ & Reduced by $50 \%$ & {$[209]$} \\
\hline \multirow[t]{2}{*}{ Horizontal flow CW } & $\begin{array}{l}\text { Raw domestic } \\
\text { wastewater }\end{array}$ & int1, tet $\mathrm{M}$, sul1, erm B and total ARGs & $\begin{array}{l}50.7-89.4 \%, 85.9-97 \% \\
49.6-92.9 \%, 58.2-96.7 \% \text { \& } \\
79.9-94.3 \%\end{array}$ & {$[33]$} \\
\hline & Hospital wastewater & $\begin{array}{l}\text { Tetracycline-, erythromycin- and } \\
\text { ampicillin-resistant and higher } \\
\text { multidrug-resistant bacteria }\end{array}$ & $80.8 \%$ to $93.2 \%$ & {$[26]$} \\
\hline
\end{tabular}


3.4. Underlying Factors and Mechanisms Involved in the Reduction of Antibiotics, ARB and ARG in $\mathrm{CW}$

The primary mechanisms of the removal of pollutants in CW are sedimentation, sunlight/UV radiation exposure, inactivation/death associated with unfavorable water chemistry, oxidation, biofilm interaction [210], predation, antibiotic or biocides secretion and natural die-off [211]. One technique that has been used to increase the capacity for ARG removal from CWs is to recirculate the effluent into the $\mathrm{CW}$ to increase the binding of extracellular DNA into the substrate [212]. Studies have reported that adsorption onto the substrate and biodegradation by the microbial population are two significant mechanisms for the removal of ARGs in CW [55,213,214]. Economics are a factor when deciding on CW substrates. Some substrates are expensive (like zeolite, oyster shell, etc.) but may be used in certain ratios to increase the microbial attachment or chemical sorption or for removal of a particular pollutant of interest. Simultaneously, redox reactions also assist in the degradation of organic substances, as reported by [215], but studies relating to varying redox conditions and ARG removal have not been reported and need to be carried out.

\subsection{Role of Plants in CWs}

Plant species, whether mono or mixed culture, are effective for the removal of antibiotic residues, ARG and other pollutants from wastewater, and accordingly, they can be selected on the basis of removal of a particular pollutant [203]. Vegetation does not directly remove ARG, but it provides oxygen to microbes, provides a surface to biofilm development and filters the solid particles. A planted $\mathrm{CW}$ has shown ARB removal of up to $81-93 \%$ as compared to unplanted constructed wetlands (42-74\%) [197]. Planted CWs have root structures that harbor populations of microbes that degrade or transform antibiotic drugs, antibiotic-resistant bacteria, and ARGs. Microorganisms are the drivers of antibiotic drug degradation, utilizing it as a carbon source. Investigations have confirmed that the root exudate helps in the degradation of pollutants and adapts the plant to the toxic effects of antibiotics [31]. The presence of Phragmites australis in CW has shown encouraging removal of ARGs and 16sRNA levels compared to other plants. Other aquatic plants such as Cyperus alternifolius, Pontederia cordata and Myriophyllum verticillatum can also contribute to the removal of ARGs [36]. A recent study on Pharagmites australis shows a tolerance mechanism and biological response to ofloxacin and sulfamethoxazole residues at even a simulated condition of $1 \mathrm{mg} / \mathrm{L}$. It was found that the growth of plants was not inhibited, and there was an improvement in root and photosynthetic activity. Low doses of antibiotics increased the transpiration and photosynthetic rate by stimulating the opening of stomata, which assisted the transportation of water and antibiotics and improved the efficiency of light utilization by acting upon the reaction center of the photosynthetic system. Individually, ofloxacin reduced the accumulation of reactive oxygen species in the plant. Both antibiotics accumulated prominently in the roots, then leaves, and finally the stem. Results demonstrated that Pharagmites is efficient in the removal of antibiotics from wastewater [214]. Studies by [216] reported that the bacterial composition in biofilms was determined by the type of substrate. The water flow increased the bacterial diversity in biofilms, and it regulated the distribution, diversity and biomass of epiphytic biofilms in $\mathrm{CW}$ with submerged macrophytes. Actinobacteria, Proteobacteria, Bacteroidetes, Firmicutes and Planctomycetes were found in the biofilm, whereas Proteobacteria, Bacteroidetes, Euryarchaeota, Thaumarchaeta were found in the sediments in different percentages. Supplementary Figure S3 demonstrates the role of macrophytes and the mechanism for the reduction of pollutants in CWs.

\section{Conclusions and Implications}

The presence of antibiotic resistance in wastewater effluents has stimulated recent studies for understanding the abundance, occurrence, fate and potential control in WWTP. CWs are another option. CWs are quite efficient for the reduction of general water pollutants, nutrients, and emerging contaminants, including antibiotic drugs, ARBs/ARGs, and 
they have demonstrated encouraging results in recent studies. CWs are considered to be a flexible treatment technology with the potential to reduce a wide variety of pollutants. CWs can be used as decentralized systems where each individual housing unit can have its own pretreatment unit as a septic tank/sedimentation tank, allowing flow to the $\mathrm{CW}$ and then the discharge of treated water. They can also be integrated with secondary and tertiary treatment in conventional wastewater treatment plants as a viable option for the reduction of the microbial load. The treated effluent can be used for gardening purposes, agriculture, artificial groundwater recharge, as direct discharge to water bodies and in industrial usages, like washing, cooling, etc. CWs find their application particularly in developing/low-income countries, where there are failures for treating wastewater due to lack of treatment plants, tertiary units, electricity and manpower cost. CWs reduce the cost of conventional treatment plants and work on a non-mechanized system. Other factors include local availability, simplified operation, reduced construction cost, ability to maintain at an individual level, enriched aesthetics to the environment, and environmental restoration. Parks and gardens can be designed according to space availability for public awareness and acceptance. According to use, multistage or hybrid CWs can be designed that further increase the performance efficiency of the system. CWs treat wastewater and make it fit for reuse purposes, providing an alternative for large volumes of effluent from wastewater treatment plants. This would otherwise be difficult to manage and pose a potential threat to the receiving environment. Hence, the use of CWs as a flexible treatment technology is recommended, with the potential for reducing antibiotic resistance. Multistage and hybrid CWs are effective for treating raw urban wastewater. The technology, if adopted, will help in meeting the national action plans in developing and low-income countries, with options to use the treated effluent for multiple purposes. Investigations are further required in the relevant direction focusing on (i) the effect of antibiotic usage and its relationship with wastewater generated from the domestic and industrial sector, (ii) the impact of residual antibiotics in the influent on the selection pressure of ARG to promote resistance, (iii) the concentration of commonly used antibiotics in the influent/effluent of WWTP that is discharged into the water bodies/agricultural land, (iv) the detection of commonly available ARGs in terms of type and concentration by the latest techniques like qPCR, (v) the lacking correlation of different water quality factors and mechanisms, which needs to be explored further, (vi) the reactivation of ARG in the effluent after chlorination or treated effluent of CWs in the water or soil matrix and the overall impact of ARG disseminated, and (vii) identifying the mechanisms underlying the removal of ARG/ARB removal in CW that is essential for designing highly effective CWs for removal of antibiotic drugs, antibiotic-resistant bacteria, and ARG.

Supplementary Materials: The following are available online at https://www.mdpi.com/article/10 .3390/antibiotics11010114/s1, Figure S1: Types of constructed wetlands according to their designs and specifications, Figure S2: Flow chart to demonstrate the steps involved for writing the present review, Figure S3: Role of macrophytes in constructed wetlands; Table S1: Comparative techno-economical assessment of target technologies based on suitability of reuse.

Author Contributions: M.H.: basic framework, drafting and writing of review, graphical representation; L.M.D.: drafting, inputs for refining the paper and English editing. All authors have read and agreed to the published version of the manuscript.

Funding: This work was supported in part by USDA National Program 212 base funding to Lisa Durso.

Institutional Review Board Statement: Not applicable.

Informed Consent Statement: Not applicable.

Data Availability Statement: Not applicable.

Conflicts of Interest: The authors declare no conflict of interest. 


\section{References}

1. Jäger, T.; Hembach, N.; Elpers, C.; Wieland, A.; Alexander, J.; Hiller, C.; Krauter, G.; Schwartz, T. Reduction of Antibiotic Resistant Bacteria During Conventional and Advanced Wastewater Treatment, and the Disseminated Loads Released to the Environment. Front. Microbiol. 2018, 9, 2599. [CrossRef]

2. Anthony, E.T.; Ojemaye, M.O.; Okoh, O.O.; Okoh, A. A critical review on the occurrence of resistomes in the environment and their removal from wastewater using apposite treatment technologies: Limitations, successes and future improvement. Environ. Pollut. 2019, 263, 113791. [CrossRef]

3. Zhang, X.-X.; Zhang, T.; Fang, H.H.P. Antibiotic resistance genes in water environment. Appl. Microbiol. Biotechnol. 2009, 82, 397-414. [CrossRef]

4. Nnadozie, C.F.; Kumari, S.; Bux, F. Status of pathogens, antibiotic resistance genes and antibiotic residues in wastewater treatment systems. Rev. Environ. Sci. Bio/Technol. 2017, 16, 491-515. [CrossRef]

5. Kampouris, I.D.; Klümper, U.; Agrawal, S.; Orschler, L.; Cacace, D.; Kunze, S.; Berendonk, T.U. Treated wastewater irrigation promotes the spread of antibiotic resistance into subsoil pore-water. Environ. Int. 2020, 146, 106190. [CrossRef] [PubMed]

6. Nappier, S.; Liguori, K.; Ichida, A.; Stewart, J.; Jones, K. Antibiotic Resistance in Recreational Waters: State of the Science. Int. J. Environ. Res. Public Health 2020, 17, 8034. [CrossRef]

7. United Nations. UN-WATER Progress on Wastewater Treatment-Piloting the Monitoring Mehtodology and Intial Findings for SDG Indicator 6.3.1; United Nations: New York, NY, USA, 2018; ISBN 8228785852.

8. O'Neill, J. Antimicrobials in Agriculture and the Environment: Reducing Unnecessary Use and Waste the Review on Antimicrobial Resistance. 2015. Available online: https://amr-review.org/sites/default/files/Antimicrobials\%20in\%20agriculture\%20and\% 20the\%20environment\%20-\%20Reducing\%20unnecessary\%20use\%20and\%20waste.pdf (accessed on 27 November 2021).

9. Bengtsson-Palme, J.; Kristiansson, E.; Larsson, D.J. Environmental factors influencing the development and spread of antibiotic resistance. FEMS Microbiol. Rev. 2017, 42, 68-89. [CrossRef] [PubMed]

10. Forsberg, K.J.; Patel, S.; Gibson, M.K.; Lauber, C.L.; Knight, R.; Fierer, N.; Dantas, G. Bacterial phylogeny structures soil resistomes across habitats. Nature 2014, 509, 612-616. [CrossRef] [PubMed]

11. Binh, C.T.T.; Heuer, H.; Kaupenjohann, M.; Smalla, K. Piggery manure used for soil fertilization is a reservoir for transferable antibiotic resistance plasmids. FEMS Microbiol. Ecol. 2008, 66, 25-37. [CrossRef]

12. Ewolters, B.; Kyselkovãi, M.; Krãgerrecklenfort, E.; Ekreuzig, R.; Esmalla, K. Transferable antibiotic resistance plasmids from biogas plant digestates often belong to the IncP-1̂̂ $\mu$ subgroup. Front. Microbiol. 2015, 5, 765. [CrossRef]

13. Khan, F.A.; Söderquist, B.; Jass, J. Prevalence and Diversity of Antibiotic Resistance Genes in Swedish Aquatic Environments Impacted by Household and Hospital Wastewater. Front. Microbiol. 2019, 10, 688. [CrossRef]

14. Huang, Z.; Zhao, W.; Xu, T.; Zheng, B.; Yin, D. Occurrence and distribution of antibiotic resistance genes in the water and sediments of Qingcaosha Reservoir, Shanghai, China. Environ. Sci. Eur. 2019, 31, 1-9. [CrossRef]

15. D'Costa, V.M.; Griffiths, E.; Wright, G. Expanding the soil antibiotic resistome: Exploring environmental diversity. Curr. Opin. Microbiol. 2007, 10, 481-489. [CrossRef] [PubMed]

16. Nesme, J.; Simonet, P. The soil resistome: A critical review on antibiotic resistance origins, ecology and dissemination potential in telluric bacteria. Environ. Microbiol. 2014, 17,913-930. [CrossRef]

17. Segawa, T.; Takeuchi, N.; Rivera, A.; Yamada, A.; Yoshimura, Y.; Barcaza, G.; Shinbori, K.; Motoyama, H.; Kohshima, S.; Ushida, K. Distribution of antibiotic resistance genes in glacier environments. Environ. Microbiol. Rep. 2012, 5, 127-134. [CrossRef] [PubMed]

18. Wang, F.; Stedtfeld, R.D.; Kim, O.-S.; Chai, B.; Yang, L.; Stedtfeld, T.M.; Hong, S.G.; Kim, D.; Lim, H.S.; Hashsham, S.A.; et al Influence of Soil Characteristics and Proximity to Antarctic Research Stations on Abundance of Antibiotic Resistance Genes in Soils. Environ. Sci. Technol. 2016, 50, 12621-12629. [CrossRef]

19. Van Goethem, M.W.; Pierneef, R.; Bezuidt, O.K.I.; Van De Peer, Y.; Cowan, D.A.; Makhalanyane, T.P. A reservoir of 'historical' antibiotic resistance genes in remote pristine Antarctic soils. Microbiome 2018, 6, 40. [CrossRef] [PubMed]

20. Barancheshme, F.; Munir, M. Strategies to Combat Antibiotic Resistance in the Wastewater Treatment Plants. Front. Microbiol. 2018, 8, 2603. [CrossRef]

21. Zhai, W.; Yang, F.; Mao, D.; Luo, Y. Fate and removal of various antibiotic resistance genes in typical pharmaceutical wastewater treatment systems. Environ. Sci. Pollut. Res. 2016, 23, 12030-12038. [CrossRef]

22. Rousham, E.K.; Unicomb, L.; Islam, M.A. Human, animal and environmental contributors to antibiotic resistance in low-resource settings: Integrating behavioural, epidemiological and One Health approaches. Proc. R. Soc. B Boil. Sci. 2018, $285,20180332$. [CrossRef]

23. Ibekwe, A.M.; Murinda, S.E.; Debroy, C.; Reddy, G.B. Potential pathogens, antimicrobial patterns and genotypic diversity ofEscherichia coliisolates in constructed wetlands treating swine wastewater. FEMS Microbiol. Ecol. 2016, 92, fiw006. [CrossRef] [PubMed]

24. Khan, H.K.; Rehman, M.Y.A.; Malik, R.N. Fate and toxicity of pharmaceuticals in water environment: An insight on their occurrence in South Asia. J. Environ. Manag. 2020, 271, 111030. [CrossRef]

25. Hussain, S.A.; Prasher, S.O. Understanding the Sorption of Ionophoric Pharmaceuticals in a Treatment Wetland. Wetlands 2011, 31, 563-571. [CrossRef]

26. Dires, S.; Birhanu, T.; Ambelu, A.; Sahilu, G. Antibiotic resistant bacteria removal of subsurface flow constructed wetlands from hospital wastewater. J. Environ. Chem. Eng. 2018, 6, 4265-4272. [CrossRef] 
27. Wang, Q.; Wang, P.; Yang, Q. Occurrence and diversity of antibiotic resistance in untreated hospital wastewater. Sci. Total Environ. 2018, 621, 990-999. [CrossRef]

28. Lu, H.; Wang, T.; Lu, S.; Liu, H.; Wang, H.; Li, C.; Liu, X.; Guo, X.; Zhao, X.; Liu, F. Performance and bacterial community dynamics of hydroponically grown Iris pseudacorus L. during the treatment of antibiotic-enriched wastewater at low/normal temperature. Ecotoxicol. Environ. Saf. 2021, 213, 111997. [CrossRef]

29. de Oliveira, M.; Frihling, B.E.F.; Velasques, J.; Filho, F.J.C.M.; Cavalheri, P.S.; Migliolo, L. Pharmaceuticals residues and xenobiotics contaminants: Occurrence, analytical techniques and sustainable alternatives for wastewater treatment. Sci. Total Environ. 2019, 705, 135568. [CrossRef] [PubMed]

30. Riaz, L.; Anjum, M.; Yang, Q.; Safeer, R.; Sikandar, A.; Ullah, H.; Shahab, A.; Yuan, W.; Wang, Q. Chapter 23. Treatment technologies and management options of antibiotics and AMR/ARGs. In Advances in Environmental Pollution Research Series, Antibiotics and Antimicrobial Resistance Genes in the Environment; Elsevier: Amsterdam, The Netherlands, 2020; Volume 1, pp. 369-393, ISBN 9780128188828. [CrossRef]

31. Huang, X.-F.; Ye, G.-Y.; Yi, N.-K.; Lu, L.-J.; Zhang, L.; Yang, L.-Y.; Xiao, L.; Liu, J. Effect of plant physiological characteristics on the removal of conventional and emerging pollutants from aquaculture wastewater by constructed wetlands. Ecol. Eng. 2019, 135, 45-53. [CrossRef]

32. Yi, X.; Tran, N.H.; Yin, T.; He, Y.; Gin, K.Y.-H. Removal of selected PPCPs, EDCs, and antibiotic resistance genes in landfill leachate by a full-scale constructed wetlands system. Water Res. 2017, 121, 46-60. [CrossRef]

33. Abou-Kandil, A.; Shibli, A.; Azaizeh, H.; Wolff, D.; Wick, A.; Jadoun, J. Fate and removal of bacteria and antibiotic resistance genes in horizontal subsurface constructed wetlands: Effect of mixed vegetation and substrate type. Sci. Total Environ. 2020, 759, 144193. [CrossRef]

34. Karimi, B.; Ehrampoush, M.H.; Jabary, H. Indicator pathogens, organic matter and LAS detergent removal from wastewater by constructed subsurface wetlands. J. Environ. Health Sci. Eng. 2014, 12, 52. [CrossRef]

35. Sleytr, K.; Tietz, A.; Langergraber, G.; Haberl, R. Investigation of bacterial removal during the filtration process in constructed wetlands. Sci. Total Environ. 2007, 380, 173-180. [CrossRef] [PubMed]

36. Chen, J.; Liu, Y.-S.; Su, H.-C.; Ying, G.-G.; Liu, F.; Liu, S.-S.; He, L.-Y.; Chen, Z.-F.; Yang, Y.-Q.; Chen, F.-R. Removal of antibiotics and antibiotic resistance genes in rural wastewater by an integrated constructed wetland. Environ. Sci. Pollut. Res. 2014, 22, 1794-1803. [CrossRef] [PubMed]

37. Vymazal, J. Constructed Wetlands for Wastewater Treatment. Water 2010, 2, 530-549. [CrossRef]

38. Bôto, M.; Almeida, C.M.R.; Mucha, A.P. Potential of Constructed Wetlands for Removal of Antibiotics from Saline Aquaculture Effluents. Water 2016, 8, 465. [CrossRef]

39. Bayati, M.; Ho, T.L.; Vu, D.C.; Wang, F.; Rogers, E.; Cuvellier, C.; Huebotter, S.; Inniss, E.C.; Udawatta, R.; Jose, S.; et al. Assessing the efficiency of constructed wetlands in removing PPCPs from treated wastewater and mitigating the ecotoxicological impacts. Int. J. Hyg. Environ. Health 2020, 231, 113664. [CrossRef]

40. Santos, F.; Almeida, C.M.R.; Ribeiro, I.; Mucha, A.P. Potential of constructed wetland for the removal of antibiotics and antibiotic resistant bacteria from livestock wastewater. Ecol. Eng. 2019, 129, 45-53. [CrossRef]

41. Ávila, C.; García-Galán, M.J.; Borrego, C.M.; Rodríguez-Mozaz, S.; García, J.; Barceló, D. New insights on the combined removal of antibiotics and ARGs in urban wastewater through the use of two configurations of vertical subsurface flow constructed wetlands. Sci. Total Environ. 2020, 755, 142554. [CrossRef]

42. Ilyas, H.; Van Hullebusch, E.D. Performance Comparison of Different Constructed Wetlands Designs for the Removal of Personal Care Products. Int. J. Environ. Res. Public Health 2020, 17, 3091. [CrossRef]

43. Engida, T.; Wu, J.; Xu, D.; Wu, Z. Review paper on treatment of industrial and domestic wastewaters using uasb reactors integrated into constructed wetlands for sustainable reuse. Appl. Ecol. Environ. Res. 2020, 18, 3101-3129. [CrossRef]

44. Nguyen, X.C.; Tran, T.P.; Hoang, V.H.; Nguyen, T.P.; Chang, S.W.; Nguyen, D.D.; Guo, W.; Kumar, A.; La, D.D.; Bach, Q.-V. Combined biochar vertical flow and free-water surface constructed wetland system for dormitory sewage treatment and reuse. Sci. Total Environ. 2020, 713, 136404. [CrossRef]

45. Zurita, F.; Carreon, A. Performance of three pilot-scale hybrid constructed wetlands for total coliforms and Escherichia coli removal from primary effluent-A 2-year study in a subtropical climate. J. Water Health 2014, 13, 446-458. [CrossRef]

46. Rahman, E.; Bin Halmi, M.I.E.; Samad, M.Y.B.A.; Uddin, K.; Mahmud, K.; Shukor, M.Y.A.; Abdullah, S.R.S.; Shamsuzzaman, S.M. Design, Operation and Optimization of Constructed Wetland for Removal of Pollutant. Int. J. Environ. Res. Public Health 2020, 17, 8339. [CrossRef] [PubMed]

47. Tilak, A.S.; Wani, S.P.; Patil, M.; Datta, A. Evaluating Wastewater Treatment Efficiency of Two Field Scale Subsurface Flow Constructed Wetlands. Curr. Sci. 2016, 110, 1764-1772. [CrossRef]

48. Capodaglio, A.G. Integrated, Decentralized Wastewater Management for Resource Recovery in Rural and Peri-Urban Areas. Resources 2017, 6, 22. [CrossRef]

49. United Nations. The Sustainable Development Goals Report 2019; United Nations publication issued by the Department of Economic and Social Affairs; United Nations: New York, NY, USA, 2019; p. 64. Available online: https://unstats.un.org/sdgs/report/2019 /The-Sustainable-Development-Goals-Report-2019.pdf (accessed on 27 November 2021).

50. Badza, T.; Tesfamariam, E.H.; Cogger, C. Sludge Stabilization Process, Drying Depth and Polymeric Material Addition: Implication on Nitrogen Content, Selected Chemical Properties and Land Requirement in Sand Drying Beds. Energies 2020, 13, 6753. [CrossRef] 
51. Vigueros, L.C.; Camperos, E.R. Vermicomposting of sewage sludge: A new technology for Mexico. Water Sci. Technol. 2002, 46, 153-158. [CrossRef]

52. Ludibeth, S.-M.; Marina, I.-E.; Vicenta, E.M. Vermicomposting of Sewage Sludge: Earthworm Population and Agronomic Advantages. Compos. Sci. Util. 2012, 20, 11-17. [CrossRef]

53. Boruszko, D. Vermicomposting as an Alternative Method of Sludge Treatment. J. Ecol. Eng. 2020, 21, 22-28. [CrossRef]

54. Bina, B.; Movahedian, H.; Kord, I. The Effect of Lime Stabilization on the Microbiological Quality of Sewage Sludge. Iran. J. Environ. Health Sci. Eng. 2004, 1, 38-42.

55. Shingare, R.P.; Thawale, P.R.; Raghunathan, K.; Mishra, A.; Kumar, S. Constructed wetland for wastewater reuse: Role and efficiency in removing enteric pathogens. J. Environ. Manag. 2019, 246, 444-461. [CrossRef]

56. Kadlec, R.H.; Wallace, S.D. Treatment Wetlands, 2nd ed.; CRC Press Taylor \& Francis Group: Boca Raton, FL, USA, 2009; p. 1016, ISBN 978-1-56670-526-4. Available online: https:/ /sswm.info/sites/default/files/reference_attachments/KADLEC\%20 WALLACE\%202009\%20Treatment\%20Wetlands\%202nd\%20Edition_0.pdf (accessed on 27 November 2021).

57. Álvarez, J.A.; Ávila, C.; Otter, P.; Kilian, R.; Istenič, D.; Rolletschek, M.; Molle, P.; Khalil, N.; Ameršek, I.; Mishra, V.K.; et al. Constructed wetlands and solar-driven disinfection technologies for sustainable wastewater treatment and reclamation in rural India: SWINGS project. Water Sci. Technol. 2017, 76, 1474-1489. [CrossRef]

58. Vivant, A.-L.; Boutin, C.; Prost-Boucle, S.; Papias, S.; Hartmann, A.; Depret, G.; Ziebal, C.; Le Roux, S.; Pourcher, A.-M. Free water surface constructed wetlands limit the dissemination of extended-spectrum beta-lactamase producing Escherichia coli in the natural environment. Water Res. 2016, 104, 178-188. [CrossRef]

59. Berglund, B.; Khan, G.A.; Weisner, S.E.; Ehde, P.M.; Fick, J.; Lindgren, P.-E. Efficient removal of antibiotics in surface-flow constructed wetlands, with no observed impact on antibiotic resistance genes. Sci. Total Environ. 2014, 476-477, 29-37. [CrossRef] [PubMed]

60. Tong, X.-N.; Wang, X.-Z.; He, X.-J.; Wang, Z.; Li, W.-X. Effects of antibiotics on microbial community structure and microbial functions in constructed wetlands treated with artificial root exudates. Environ. Sci. Process. Impacts 2019, 22, 217-226. [CrossRef]

61. Almuktar, S.A.A.A.N.; Abed, S.N.; Scholz, M. Wetlands for wastewater treatment and subsequent recycling of treated effluent: A review. Environ. Sci. Pollut. Res. 2018, 25, 23595-23623. [CrossRef]

62. Kumar, D.; Asolekar, S.R.; Sharma, S.K. Post-treatment and reuse of secondary effluents using natural ltreatment systems: The Indian practices. Environ. Monit. Assess. 2015, 187, 612. [CrossRef] [PubMed]

63. Hiller, C.; Hübner, U.; Fajnorova, S.; Schwartz, T.; Drewes, J. Antibiotic microbial resistance (AMR) removal efficiencies by conventional and advanced wastewater treatment processes: A review. Sci. Total Environ. 2019, 685, 596-608. [CrossRef]

64. Triggiano, F.; Calia, C.; Diella, G.; Montagna, M.T.; De Giglio, O.; Caggiano, G. The Role of Urban Wastewater in the Environmental Transmission of Antimicrobial Resistance: The Current Situation in Italy (2010-2019). Microorganisms 2020, 8, 1567. [CrossRef] [PubMed]

65. Rizzo, L.; Gernjak, W.; Krzeminski, P.; Malato, S.; McArdell, C.S.; Perez, J.A.S.; Schaar, H.; Fatta-Kassinos, D. Best available technologies and treatment trains to address current challenges in urban wastewater reuse for irrigation of crops in EU countries. Sci. Total Environ. 2019, 710, 136312. [CrossRef]

66. King, T.; Schmidt, S.; Essack, S. Antibiotic resistant Klebsiella spp. from a hospital, hospital effluents and wastewater treatment plants in the uMgungundlovu District, KwaZulu-Natal, South Africa. Sci. Total Environ. 2019, 712, 135550. [CrossRef] [PubMed]

67. Sydnor, E.R.M.; Perl, T.M. Hospital Epidemiology and Infection Control in Acute-Care Settings. Clin. Microbiol. Rev. 2011, 24, 141-173. [CrossRef] [PubMed]

68. Zaheer, R.; Cook, S.R.; Barbieri, R.; Goji, N.; Cameron, A.; Petkau, A.; Polo, R.O.; Tymensen, L.; Stamm, C.; Song, J.; et al Surveillance of Enterococcus spp. reveals distinct species and antimicrobial resistance diversity across a One-Health continuum. Sci. Rep. 2020, 10, 3937, Corrected in Sci Rep. 2020, 10, 13401. [CrossRef]

69. Hayakawa, K.; Marchaim, D.; Martin, E.T.; Tiwari, N.; Yousuf, A.; Sunkara, B.; Pulluru, H.; Kotra, H.; Hasan, A.; Bheemreddy, S.; et al. Comparison of the Clinical Characteristics and Outcomes Associated with Vancomycin-Resistant Enterococcus faecalis and Vancomycin-Resistant E. faecium Bacteremia. Antimicrob. Agents Chemother. 2012, 56, 2452-2458. [CrossRef] [PubMed]

70. Huijbers, P.M.; Larsson, D.J.; Flach, C.-F. Surveillance of antibiotic resistant Escherichia coli in human populations through urban wastewater in ten European countries. Environ. Pollut. 2020, 261, 114200. [CrossRef]

71. Duong, H.A.; Phung, T.V.; Nguyen, T.N.; Thi, L.-A.P.; Pham, H.V. Occurrence, Distribution, and Ecological Risk Assessment of Antibiotics in Selected Urban Lakes of Hanoi, Vietnam. J. Anal. Methods Chem. 2021, 2021, 1-13. [CrossRef]

72. Felis, E.; Kalka, J.; Sochacki, A.; Kowalska, K.; Bajkacz, S.; Harnisz, M.; Korzeniewska, E. Antimicrobial pharmaceuticals in the aquatic environment-occurrence and environmental implications. Eur. J. Pharmacol. 2019, 866, 172813. [CrossRef]

73. Miller, S.I. Antibiotic Resistance and Regulation of the Gram-Negative Bacterial Outer Membrane Barrier by Host Innate Immune Molecules. mBio 2016, 7, e01541-16. [CrossRef]

74. Delcour, A.H. Outer membrane permeability and antibiotic resistance. Biochim. Biophys. Acta. 2009, 1794, 808-816. [CrossRef]

75. Hendricks, R.; Pool, E.J. The effectiveness of sewage treatment processes to remove faecal pathogens and antibiotic residues. $J$. Environ. Sci. Health Part A 2012, 47, 289-297. [CrossRef] [PubMed]

76. Li, W.; Shi, Y.; Gao, L.; Liu, J.; Cai, Y. Occurrence and removal of antibiotics in a municipal wastewater reclamation plant in Beijing, China. Chemosphere 2013, 92, 435-444. [CrossRef] [PubMed] 
77. Batchu, S.R.; Panditi, V.R.; O'Shea, K.E.; Gardinali, P.R. Photodegradation of antibiotics under simulated solar radiation: Implications for their environmental fate. Sci. Total Environ. 2014, 470-471, 299-310. [CrossRef]

78. Chopra, I.; Shales, S. Susceptibility of Protein Synthesis in Escherichia coli to Tetracycline and Minocycline. Microbiology 1981, 124, 187-189. [CrossRef]

79. Wu, W.; Yang, L.; Wang, J. Denitrification performance and microbial diversity in a packed-bed bioreactor using PCL as carbon source and biofilm carrier. Appl. Microbiol. Biotechnol. 2012, 97, 2725-2733. [CrossRef] [PubMed]

80. Yao, N.; Li, C.; Yu, J.; Xu, Q.; Wei, S.; Tian, Z.; Yang, Z.; Yang, W.; Shen, J. Insight into adsorption of combined antibiotic-heavy metal contaminants on graphene oxide in water. Sep. Purif. Technol. 2019, 236, 116278. [CrossRef]

81. Moles, S.; Valero, P.; Escuadra, S.; Mosteo, R.; Gómez, J.; Ormad, M.P. Performance comparison of commercial TiO2: Separation and reuse for bacterial photo-inactivation and emerging pollutants photo-degradation. Environ. Sci. Pollut. Res. 2020, 27, 9099-9113. [CrossRef]

82. van Grieken, R.; Marugán, J.; Pablos, C.; Furones, L.; López, A. Comparison between the photocatalytic inactivation of Grampositive E. faecalis and Gram-negative E. coli faecal contamination indicator microorganisms. Appl. Catal. B Environ. 2010, 100, 212-220. [CrossRef]

83. Jia, A.; Wan, Y.; Xiao, Y.; Hu, J. Occurrence and fate of quinolone and fluoroquinolone antibiotics in a municipal sewage treatment plant. Water Res. 2012, 46, 387-394. [CrossRef]

84. Behera, S.K.; Kim, H.-W.; Oh, J.-E.; Park, H.-S. Occurrence and removal of antibiotics, hormones and several other pharmaceuticals in wastewater treatment plants of the largest industrial city of Korea. Sci. Total Environ. 2011, 409, 4351-4360. [CrossRef]

85. Marx, C.; Günther, N.; Schubert, S.; Oertel, R.; Ahnert, M.; Krebs, P.; Kuehn, V. Mass flow of antibiotics in a wastewater treatment plant focusing on removal variations due to operational parameters. Sci. Total Environ. 2015, 538, 779-788. [CrossRef]

86. Vieno, N.; Tuhkanen, T.; Kronberg, L. Elimination of pharmaceuticals in sewage treatment plants in Finland. Water Res. 2007, 41, 1001-1012. [CrossRef]

87. Li, B.; Zhang, T. Biodegradation and Adsorption of Antibiotics in the Activated Sludge Process. Environ. Sci. Technol. 2010, 44, 3468-3473. [CrossRef] [PubMed]

88. Li, B.; Zhang, T. Mass flows and removal of antibiotics in two municipal wastewater treatment plants. Chemosphere 2011, 83, 1284-1289. [CrossRef] [PubMed]

89. Lin, A.Y.-C.; Tsai, Y.-T. Occurrence of pharmaceuticals in Taiwan's surface waters: Impact of waste streams from hospitals and pharmaceutical production facilities. Sci. Total Environ. 2009, 407, 3793-3802. [CrossRef]

90. De la Cruz, N.; Gimenez, J.; Esplugas, S.; Grandjean, D.; de Alencastro, L.; Pulgarín, C. Degradation of 32 emergent contaminants by UV and neutral photo-fenton in domestic wastewater effluent previously treated by activated sludge. Water Res. 2012, 46, 1947-1957. [CrossRef] [PubMed]

91. Ben, W.; Zhu, B.; Yuan, X.; Zhang, Y.; Yang, M.; Qiang, Z. Occurrence, removal and risk of organic micropollutants in wastewater treatment plants across China: Comparison of wastewater treatment processes. Water Res. 2018, 130, 38-46. [CrossRef]

92. Xu, W.; Zhang, G.; Li, X.; Zou, S.; Li, P.; Hu, Z.; Li, J. Occurrence and elimination of antibiotics at four sewage treatment plants in the Pearl River Delta (PRD), South China. Water Res. 2007, 41, 4526-4534. [CrossRef]

93. Hollender, J.; Zimmermann, S.G.; Koepke, S.; Krauss, M.; McArdell, C.S.; Ort, C.; Singer, H.; von Gunten, U.; Siegrist, H. Elimination of Organic Micropollutants in a Municipal Wastewater Treatment Plant Upgraded with a Full-Scale Post-Ozonation Followed by Sand Filtration. Environ. Sci. Technol. 2009, 43, 7862-7869. [CrossRef]

94. Alajmi, H.M. Effect of Physical, Chemical and Biological Treatment on the Removal of Five Pharmaceuticals from Domestic Wastewater in Laboratory-Scale Reactors and a Full-Scale Plant. Ph.D. Thesis, Newcastle University, Newcastle upon Tyne, UK, 2014. Available online: https://theses.ncl.ac.uk/jspui/bitstream/10443/2469/1/Alajmi\%2C\%20H.\%2014.pdf (accessed on 27 November 2021).

95. Altmann, J.; Ruhl, A.S.; Zietzschmann, F.; Jekel, M. Direct comparison of ozonation and adsorption onto powdered activated carbon for micropollutant removal in advanced wastewater treatment. Water Res. 2014, 55, 185-193. [CrossRef]

96. Nam, S.-W.; Choi, D.-J.; Kim, S.-K.; Her, N.; Zoh, K.-D. Adsorption characteristics of selected hydrophilic and hydrophobic micropollutants in water using activated carbon. J. Hazard. Mater. 2014, 270, 144-152. [CrossRef] [PubMed]

97. Verlicchi, P.; Al Aukidy, M.; Zambello, E. Occurrence of pharmaceutical compounds in urban wastewater: Removal, mass load and environmental risk after a secondary treatment-A review. Sci. Total Environ. 2012, 429, 123-155. [CrossRef]

98. Phoon, B.L.; Ong, C.C.; Saheed, M.S.M.; Show, P.-L.; Chang, J.-S.; Ling, T.C.; Lam, S.S.; Juan, J.C. Conventional and emerging technologies for removal of antibiotics from wastewater. J. Hazard. Mater. 2020, 400, 122961. [CrossRef]

99. Tang, J.; Wang, J. Fenton-like degradation of sulfamethoxazole using Fe-based magnetic nanoparticles embedded into mesoporous carbon hybrid as an efficient catalyst. Chem. Eng. J. 2018, 351, 1085-1094. [CrossRef]

100. Chen, L.; Zhou, Z.; Shen, C.; Xu, Y. Inactivation of antibiotic-resistant bacteria and antibiotic resistance genes by electrochemical oxidation/electro-Fenton process. Water Sci. Technol. 2020, 81, 2221-2231. [CrossRef] [PubMed]

101. Guerra-Rodríguez, S.; Rodríguez, E.; Singh, D.N.; Rodríguez-Chueca, J. Assessment of Sulfate Radical-Based Advanced Oxidation Processes for Water and Wastewater Treatment: A Review. Water 2018, 10, 1828. [CrossRef]

102. Wang, S.; Wang, J. Oxidative removal of carbamazepine by peroxymonosulfate (PMS) combined to ionizing radiation: Degradation, mineralization and biological toxicity. Sci. Total Environ. 2019, 658, 1367-1374. [CrossRef] [PubMed] 
103. Zhuan, R.; Wang, J. Degradation of sulfamethoxazole by ionizing radiation: Kinetics and implications of additives. Sci. Total Environ. 2019, 668, 67-73. [CrossRef] [PubMed]

104. Al-Jassim, N.; Ansari, M.I.; Harb, M.; Hong, P.-Y. Removal of bacterial contaminants and antibiotic resistance genes by conventional wastewater treatment processes in Saudi Arabia: Is the treated wastewater safe to reuse for agricultural irrigation? Water Res. 2015, 73, 277-290. [CrossRef] [PubMed]

105. Reinthaler, F.; Posch, J.; Feierl, G.; Wüst, G.; Haas, D.; Ruckenbauer, G.; Mascher, F.; Marth, E. Antibiotic resistance of E. coli in sewage and sludge. Water Res. 2003, 37, 1685-1690. [CrossRef]

106. Varela, A.R.; Ferro, G.; Vredenburg, J.; Yanık, M.; Vieira, L.; Rizzo, L.; Lameiras, C.; Manaia, C.M. Vancomycin resistant enterococci: From the hospital effluent to the urban wastewater treatment plant. Sci. Total Environ. 2013, 450-451, 155-161. [CrossRef]

107. Munir, M.; Wong, K.; Xagoraraki, I. Release of antibiotic resistant bacteria and genes in the effluent and biosolids of five wastewater utilities in Michigan. Water Res. 2011, 45, 681-693. [CrossRef] [PubMed]

108. Saxena, P.; Hiwrale, I.; Das, S.; Shukla, V.; Tyagi, L.; Pal, S.; Dafale, N.; Dhodapkar, R. Profiling of emerging contaminants and antibiotic resistance in sewage treatment plants: An Indian perspective. J. Hazard. Mater. 2020, 408, 124877. [CrossRef] [PubMed]

109. Marín, I.; Goñi, P.; Lasheras, A.; Ormad, M. Efficiency of a Spanish wastewater treatment plant for removal potentially pathogens: Characterization of bacteria and protozoa along water and sludge treatment lines. Ecol. Eng. 2015, 74, 28-32. [CrossRef]

110. Szostkova, M.; Vitez, T.; Marecek, J.; Losak, T. Microbial Contamination of Screenings from Wastewater Treatment Plants. Pol. J. Environ. Stud. 2012, 21, 1943-1947.

111. WHO. Guidelines for Safe Use of Wastewater, Excreta and Greywater. (Volume IV: Excreta and Greywater Use in Agriculture); World Health Organization (WHO): Geneva, Switzerland, 2006; ISBN 9241546859. Available online: https://www.who.int/publications/ i/item/9241546859 (accessed on 27 November 2021).

112. Teshome, A.; Alemayehu, T.; Deriba, W.; Ayele, A.T. Antibiotic Resistance Profile of Bacteria Isolated from Wastewater Systems in Eastern Ethiopia. J. Environ. Public Health 2020, 2020, 1-10. [CrossRef] [PubMed]

113. Barrios-Hernández, M.L.; Pronk, M.; Garcia, H.; Boersma, A.; Brdjanovic, D.; van Loosdrecht, M.C.; Hooijmans, C.M. Removal of bacterial and viral indicator organisms in full-scale aerobic granular sludge and conventional activated sludge systems. Water Res. X 2019, 6, 100040. [CrossRef]

114. Mao, G.; Song, Y.; Bartlam, M.; Wang, Y. Long-Term Effects of Residual Chlorine on Pseudomonas aeruginosa in Simulated Drinking Water Fed With Low AOC Medium. Front. Microbiol. 2018, 9, 879. [CrossRef]

115. Owoseni, M.C.; Olaniran, A.O.; Okoh, A.I. Chlorine Tolerance and Inactivation of Escherichia coli recovered from Wastewater Treatment Plants in the Eastern Cape, South Africa. Appl. Sci. 2017, 7, 810. [CrossRef]

116. Lv, L.; Jiang, T.; Zhang, S.; Yu, X. Exposure to Mutagenic Disinfection Byproducts Leads to Increase of Antibiotic Resistance in Pseudomonas aeruginosa. Environ. Sci. Technol. 2014, 48, 8188-8195. [CrossRef]

117. Zhang, Y.; Zhuang, Y.; Geng, J.; Ren, H.; Zhang, Y.; Ding, L.; Xu, K. Inactivation of antibiotic resistance genes in municipal wastewater effluent by chlorination and sequential UV/chlorination disinfection. Sci. Total Environ. 2015, 512-513, 125-132. [CrossRef]

118. Huang, J.-J.; Hu, H.-Y.; Tang, F.; Li, Y.; Lu, S.-Q.; Lu, Y. Inactivation and reactivation of antibiotic-resistant bacteria by chlorination in secondary effluents of a municipal wastewater treatment plant. Water Res. 2011, 45, 2775-2781. [CrossRef]

119. Du, J.; Geng, J.; Ren, H.; Ding, L.; Xu, K.; Zhang, Y. Variation of antibiotic resistance genes in municipal wastewater treatment plant with A2O-MBR system. Environ. Sci. Pollut. Res. 2014, 22, 3715-3726. [CrossRef] [PubMed]

120. Bouki, C.; Venieri, D.; Diamadopoulos, E. Detection and fate of antibiotic resistant bacteria in wastewater treatment plants: A review. Ecotoxicol. Environ. Saf. 2013, 91, 1-9. [CrossRef]

121. Teklehaimanot, G.Z.; Genthe, B.; Kamika, I.; Momba, M. Prevalence of enteropathogenic bacteria in treated effluents and receiving water bodies and their potential health risks. Sci. Total Environ. 2015, 518-519, 441-449. [CrossRef] [PubMed]

122. Yuan, Q.-B.; Guo, M.; Yang, J. Fate of Antibiotic Resistant Bacteria and Genes during Wastewater Chlorination: Implication for Antibiotic Resistance Control. PLoS ONE 2015, 10, e0119403. [CrossRef]

123. Thayanukul, P.; Kurisu, F.; Kasuga, I.; Furumai, H. Evaluation of microbial regrowth potential by assimilable organic carbon in various reclaimed water and distribution systems. Water Res. 2013, 47, 225-232. [CrossRef] [PubMed]

124. Lin, Y.-W.; Li, D.; Gu, A.Z.; Zeng, S.-Y.; He, M. Bacterial regrowth in water reclamation and distribution systems revealed by viable bacterial detection assays. Chemosphere 2016, 144, 2165-2174. [CrossRef] [PubMed]

125. Kim, S.; Park, H.; Chandran, K. Propensity of activated sludge to amplify or attenuate tetracycline resistance genes and tetracycline resistant bacteria: A mathematical modeling approach. Chemosphere 2010, 78, 1071-1077. [CrossRef]

126. Guo, M.-T.; Yuan, Q.-B.; Yang, J. Ultraviolet reduction of erythromycin and tetracycline resistant heterotrophic bacteria and their resistance genes in municipal wastewater. Chemosphere 2013, 93, 2864-2868. [CrossRef]

127. Lüddeke, F.; Heß, S.; Gallert, C.; Winter, J.; Güde, H.; Löffler, H. Removal of total and antibiotic resistant bacteria in advanced wastewater treatment by ozonation in combination with different filtering techniques. Water Res. 2015, 69, 243-251. [CrossRef]

128. Alexander, J.; Knopp, G.; Dötsch, A.; Wieland, A.; Schwartz, T. Ozone treatment of conditioned wastewater selects antibiotic resistance genes, opportunistic bacteria, and induce strong population shifts. Sci. Total Environ. 2016, 559, 103-112. [CrossRef] [PubMed]

129. Ternes, T.A.; Stüber, J.; Herrmann, N.; McDowell, D.; Ried, A.; Kampmann, M.; Teiser, B. Ozonation: A tool for removal of pharmaceuticals, contrast media and musk fragrances from wastewater? Water Res. 2003, 37, 1976-1982. [CrossRef] 
130. Xu, P.; Janex, M.-L.; Savoye, P.; Cockx, A.; Lazarova, V. Wastewater disinfection by ozone: Main parameters for process design. Water Res. 2001, 36, 1043-1055. [CrossRef]

131. Vymazal, J. Removal of Enteric Bacteria in Constructed Treatment Wetlands with Emergent Macrophytes: A Review. J. Environ. Sci. Health Part A 2005, 40, 1355-1367. [CrossRef] [PubMed]

132. Nguyen, X.C.; Nguyen, D.D.; Tran, Q.B.; Nguyen, T.T.H.; Tran, T.K.A.; Tran, T.C.P.; Nguyen, T.H.G.; Tran, T.N.T.; La, D.D.; Chang, S.W.; et al. Two-step system consisting of novel vertical flow and free water surface constructed wetland for effective sewage treatment and reuse. Bioresour. Technol. 2020, 306, 123095. [CrossRef]

133. Quansah, A.; Ntaryamira, T.; Rwemera, J. Sludge Wastewater Management by Conventional Treatment Process: Case StudyBujumbura Municipal Sewage. Int. J. Sci. 2018, 4, 52-65. [CrossRef]

134. Bunce, J.T.; Ndam, E.; Ofiteru, I.D.; Moore, A.; Graham, D.W. A Review of Phosphorus Removal Technologies and Their Applicability to Small-Scale Domestic Wastewater Treatment Systems. Front. Environ. Sci. 2018, 6, 8. [CrossRef]

135. Li, N.; Sheng, G.-P.; Lu, Y.-Z.; Zeng, R.J.; Yu, H.-Q. Removal of antibiotic resistance genes from wastewater treatment plant effluent by coagulation. Water Res. 2017, 111, 204-212. [CrossRef] [PubMed]

136. Guan, Y.; Wang, B.; Gao, Y.; Liu, W.; Zhao, X.; Huang, X.; Yu, J. Occurrence and Fate of Antibiotics in the Aqueous Environment and Their Removal by Constructed Wetlands in China: A review. Pedosphere 2017, 27, 42-51. [CrossRef]

137. Zhang, Z.; Li, B.; Li, N.; Sardar, M.F.; Song, T.; Zhu, C.; Lv, X.; Li, H. Effects of UV disinfection on phenotypes and genotypes of antibiotic-resistant bacteria in secondary effluent from a municipal wastewater treatment plant. Water Res. 2019, 157, 546-554. [CrossRef] [PubMed]

138. Ding, H.; Qiao, M.; Zhong, J.; Zhu, Y.; Guo, C.; Zhang, Q.; Yang, P.; Han, L.; Zhang, W.; Wu, Y.; et al. Characterization of antibiotic resistance genes and bacterial community in selected municipal and industrial sewage treatment plants beside Poyang Lake. Water Res. 2020, 174, 115603. [CrossRef]

139. Chen, H.; Zhang, M. Occurrence and removal of antibiotic resistance genes in municipal wastewater and rural domestic sewage treatment systems in eastern China. Environ. Int. 2013, 55, 9-14. [CrossRef]

140. Börjesson, S.; Dienues, O.; Jarnheimer, P.; Olsen, B.; Matussek, A.; Lindgren, P.-E. Quantification of genes encoding resistance to aminoglycosides, $\beta$-lactams and tetracyclines in wastewater environments by real-time PCR. Int. J. Environ. Health Res. 2009, 19, 219-230. [CrossRef]

141. Pei, M.; Zhang, B.; He, Y.; Su, J.; Gin, K.; Lev, O.; Shen, G.; Hu, S. State of the art of tertiary treatment technologies for controlling antibiotic resistance in wastewater treatment plants. Environ. Int. 2019, 131, 105026. [CrossRef] [PubMed]

142. Korzeniewska, E.; Harnisz, M. Relationship between modification of activated sludge wastewater treatment and changes in antibiotic resistance of bacteria. Sci. Total Environ. 2018, 639, 304-315. [CrossRef]

143. Gao, P.; Munir, M.; Xagoraraki, I. Correlation of tetracycline and sulfonamide antibiotics with corresponding resistance genes and resistant bacteria in a conventional municipal wastewater treatment plant. Sci. Total Environ. 2012, 421-422, 173-183. [CrossRef]

144. Rodriguez-Mozaz, S.; Chamorro, S.; Marti, E.; Huerta, B.; Gros, M.; Sànchez-Melsió, A.; Borrego, C.M.; Barceló, D.; Balcázar, J.L. Occurrence of antibiotics and antibiotic resistance genes in hospital and urban wastewaters and their impact on the receiving river. Water Res. 2015, 69, 234-242. [CrossRef] [PubMed]

145. Stiborova, H.; Kracmarova, M.; Vesela, T.; Biesiekierska, M.; Cerny, J.; Balik, J.; Demnerova, K. Impact of Long-Term Manure and Sewage Sludge Application to Soil as Organic Fertilizer on the Incidence of Pathogenic Microorganisms and Antibiotic Resistance Genes. Agronomy 2021, 11, 1423. [CrossRef]

146. Thakali, O.; Brooks, J.P.; Shahin, S.; Sherchan, S.P.; Haramoto, E. Removal of Antibiotic Resistance Genes at Two Conventional Wastewater Treatment Plants of Louisiana, USA. Water 2020, 12, 1729. [CrossRef]

147. Huang, J.J.; Xi, J.Y.; Hu, H.Y.; Tang, F.; Pang, Y.C. Inactivation and regrowth of antibiotic-resistant bacteria by PAA disinfection in the secondary effluent of a municipal wastewater treatment plant. Biomed. Environ. Sci. 2013, 26, 865-868. [CrossRef]

148. Jin, M.; Liu, L.; Wang, D.-N.; Yang, D.; Liu, W.-L.; Yin, J.; Yang, Z.-W.; Wang, H.-R.; Qiu, Z.-G.; Shen, Z.-Q.; et al. Chlorine disinfection promotes the exchange of antibiotic resistance genes across bacterial genera by natural transformation. ISME J. 2020, 14, 1847-1856. [CrossRef]

149. Sharma, V.K.; Yu, X.; McDonald, T.J.; Jinadatha, C.; Dionysiou, D.; Feng, M. Elimination of antibiotic resistance genes and control of horizontal transfer risk by UV-based treatment of drinking water: A mini review. Front. Environ. Sci. Eng. 2019, 13, 1-9. [CrossRef]

150. Zheng, J.; Su, C.; Zhou, J.; Xu, L.; Qian, Y.; Chen, H. Effects and mechanisms of ultraviolet, chlorination, and ozone disinfection on antibiotic resistance genes in secondary effluents of municipal wastewater treatment plants. Chem. Eng. J. 2017, 317, 309-316. [CrossRef]

151. Shekhawat, S.S.; Kulshreshtha, N.M.; Gupta, A.B. Investigation of chlorine tolerance profile of dominant gram negative bacteria recovered from secondary treated wastewater in Jaipur, India. J. Environ. Manag. 2019, 255, 109827. [CrossRef]

152. Jiang, H.; Zhou, R.; Yang, Y.; Chen, B.; Cheng, Z.; Zhang, M.; Li, J.; Zhang, G.; Zou, S. Characterizing the antibiotic resistance genes in a river catchment: Influence of anthropogenic activities. J. Environ. Sci. 2018, 69, 125-132. [CrossRef]

153. Sinha, R.P.; Häder, D.-P. UV-induced DNA damage and repair: A review. Photochem. Photobiol. Sci. 2002, 1, 225-236. [CrossRef] [PubMed] 
154. Ávila, C.; Pelissari, C.; Sezerino, P.H.; Sgroi, M.; Roccaro, P.; García, J. Enhancement of total nitrogen removal through effluent recirculation and fate of PPCPs in a hybrid constructed wetland system treating urban wastewater. Sci. Total Environ. 2017, 584-585, 414-425. [CrossRef] [PubMed]

155. Stefanakis, A.I.; Akratos, C.S. Phytoremediation: Management of Environmental Contaminants, Volume 4. In Phytoremediation: Management of Environmental Contaminants; Springer: Cham, Switzerland, 2016; Volume 4, pp. 1-409. [CrossRef]

156. Rosal, R.; Rodriguez, A.; Perdigón-Melón, J.A.; Petre, A.; García-Calvo, E. Oxidation of dissolved organic matter in the effluent of a sewage treatment plant using ozone combined with hydrogen peroxide $\left(\mathrm{O}_{3} / \mathrm{H}_{2} \mathrm{O}_{2}\right)$. Chem. Eng. J. 2009, 149, 311-318. [CrossRef]

157. van Gijn, K.; Sohier, J.; Maasdam, R.; de Wilt, H.; Rijnaarts, H.; Langenhoff, A. Optimizing Micropollutant Removal by Ozonation; Interference of Effluent Organic Matter Fractions. Ozone Sci. Eng. 2021, 43, 579-591. [CrossRef]

158. Zhang, L.; Shen, Z.; Fang, W.; Gao, G. Composition of bacterial communities in municipal wastewater treatment plant. Sci. Total Environ. 2019, 689, 1181-1191. [CrossRef]

159. Zhang, Z.; Liu, H.; Wang, Q. Free Ammonia Pretreatment for Anaerobic Sludge Digestion Reduces the Spread of Antibiotic Resistance. bioRxiv 2020, 2-12. [CrossRef]

160. Ezzat, S.M.; Moustafa, M.T. Treating wastewater under zero waste principle using wetland mesocosms. Front. Environ. Sci. Eng. 2020, 15, 1-14. [CrossRef]

161. Jamwal, P.; Raj, A.V.; Raveendran, L.; Shirin, S.; Connelly, S.; Yeluripati, J.; Richards, S.; Rao, L.; Helliwell, R.; Tamburini, M. Evaluating the performance of horizontal sub-surface flow constructed wetlands: A case study from southern India. Ecol. Eng. 2021, 162, 106170. [CrossRef]

162. Lopardo, C.R.; Zhang, L.; Mitsch, W.J.; Urakawa, H. Comparison of nutrient retention efficiency between vertical-flow and floating treatment wetland mesocosms with and without biodegradable plastic. Ecol. Eng. 2019, 131, 120-130. [CrossRef]

163. Si, Z.; Wang, Y.; Song, X.; Cao, X.; Zhang, X.; Sand, W. Mechanism and performance of trace metal removal by continuous-flow constructed wetlands coupled with a micro-electric field. Water Res. 2019, 164, 114937. [CrossRef] [PubMed]

164. Yang, Y.; Shen, Q. Phytoremediation of cadmium-contaminated wetland soil with Typha latifolia L. and the underlying mechanisms involved in the heavy-metal uptake and removal. Environ. Sci. Pollut. Res. 2019, 27, 4905-4916. [CrossRef] [PubMed]

165. Vivant, A.-L.; Boutin, C.; Prost-Boucle, S.; Papias, S.; Ziebal, C.; Pourcher, A.-M. Fate of two strains of extended-spectrum beta-lactamase producing Escherichia coli in constructed wetland microcosm sediments: Survival and change in antibiotic resistance profiles. Water Sci. Technol. 2019, 79, 1550-1560. [CrossRef]

166. Stokes, J.M.; Lopatkin, A.J.; Lobritz, M.A.; Collins, J.J. Bacterial Metabolism and Antibiotic Efficacy. Cell Metab. 2019, 30, 251-259. [CrossRef]

167. Chen, L.; Huang, F.; Zhang, C.; Zhang, J.; Liu, F.; Guan, X. Effects of norfloxacin on nitrate reduction and dynamic denitrifying enzymes activities in groundwater. Environ. Pollut. 2021, 273, 116492. [CrossRef]

168. Semedo, M.; Song, B.; Sparrer, T.; Phillips, R. Antibiotic Effects on Microbial Communities Responsible for Denitrification and N2O Production in Grassland Soils. Front. Microbiol. 2018, 9, 2121. [CrossRef]

169. Hou, L.; Yin, G.; Liu, M.; Zhou, J.; Zheng, Y.; Gao, J.; Zong, H.; Yang, Y.; Gao, L.; Tong, C. Effects of Sulfamethazine on Denitrification and the Associated N2O Release in Estuarine and Coastal Sediments. Environ. Sci. Technol. 2014, 49, 326-333. [CrossRef] [PubMed]

170. Fan, N.-S.; Bai, Y.-H.; Chen, Q.-Q.; Shen, Y.-Y.; Huang, B.-C.; Jin, R.-C. Deciphering the toxic effects of antibiotics on denitrification: Process performance, microbial community and antibiotic resistance genes. J. Environ. Manag. 2020, 262, 110375. [CrossRef] [PubMed]

171. Faulwetter, J.L.; Gagnon, V.; Sundberg, C.; Chazarenc, F.; Burr, M.D.; Brisson, J.; Camper, A.K.; Stein, O.R. Microbial processes influencing performance of treatment wetlands: A review. Ecol. Eng. 2009, 35, 987-1004. [CrossRef]

172. Helt, C.D.; Weber, K.P.; Legge, R.L.; Slawson, R.M. Antibiotic resistance profiles of representative wetland bacteria and faecal indicators following ciprofloxacin exposure in lab-scale constructed mesocosms. Ecol. Eng. 2012, 39, 113-122. [CrossRef]

173. Yang, L.; Wen, Q.; Zhao, Y.; Chen, Z.; Wang, Q.; Bürgmann, H. New insight into effect of antibiotics concentration and process configuration on the removal of antibiotics and relevant antibiotic resistance genes. J. Hazard. Mater. 2019, 373, 60-66. [CrossRef]

174. Li, X.; Zhu, W.; Meng, G.; Zhang, C.; Guo, R. Efficiency and kinetics of conventional pollutants and tetracyclines removal in integrated vertical-flow constructed wetlands enhanced by aeration. J. Environ. Manag. 2020, 273, 111120. [CrossRef]

175. Chen, J.; Tong, T.; Jiang, X.; Xie, S. Biodegradation of sulfonamides in both oxic and anoxic zones of vertical flow constructed wetland and the potential degraders. Environ. Pollut. 2020, 265, 115040. [CrossRef] [PubMed]

176. Nivala, J.; Kahl, S.; Boog, J.; van Afferden, M.; Reemtsma, T.; Müller, R.A. Dynamics of emerging organic contaminant removal in conventional and intensified subsurface flow treatment wetlands. Sci. Total Environ. 2018, 649, 1144-1156. [CrossRef] [PubMed]

177. Kahl, S.; Nivala, J.; van Afferden, M.; Müller, R.A.; Reemtsma, T. Effect of design and operational conditions on the performance of subsurface flow treatment wetlands: Emerging organic contaminants as indicators. Water Res. 2017, 125, 490-500. [CrossRef] [PubMed]

178. Fernandes, J.; Almeida, C.M.R.; Pereira, A.C.; Ribeiro, I.L.; Reis, I.; Carvalho, P.; Basto, M.C.; Mucha, A.P. Microbial community dynamics associated with veterinary antibiotics removal in constructed wetlands microcosms. Bioresour. Technol. 2015, 182, 26-33. [CrossRef] [PubMed] 
179. Pelissari, C.; Ávila, C.; Trein, C.M.; García, J.; de Armas, R.D.; Sezerino, P.H. Nitrogen transforming bacteria within a full-scale partially saturated vertical subsurface flow constructed wetland treating urban wastewater. Sci. Total Environ. 2017, 574, 390-399. [CrossRef]

180. He, Y.; Nurul, S.; Schmitt, H.; Sutton, N.B.; Murk, T.A.; Blokland, M.; Rijnaarts, H.H.; Langenhoff, A.A. Evaluation of attenuation of pharmaceuticals, toxic potency, and antibiotic resistance genes in constructed wetlands treating wastewater effluents. Sci. Total Environ. 2018, 631-632, 1572-1581. [CrossRef]

181. Liu, X.-H.; Guo, X.; Liu, Y.; Lu, S.; Xi, B.; Zhang, J.; Wang, Z.; Bi, B. A review on removing antibiotics and antibiotic resistance genes from wastewater by constructed wetlands: Performance and microbial response. Environ. Pollut. 2019, 254, 112996. [CrossRef]

182. Yuan, Y.; Yang, B.; Wang, H.; Lai, X.; Li, F.; Salam, M.M.A.; Pan, F.; Zhao, Y. The simultaneous antibiotics and nitrogen removal in vertical flow constructed wetlands: Effects of substrates and responses of microbial functions. Bioresour. Technol. 2020, 310, 123419. [CrossRef] [PubMed]

183. Sochacki, A.; Felis, E.; Bajkacz, S.; Nowrotek, M.; Miksch, K. Removal and transformations of diclofenac and sulfamethoxazole in a two-stage constructed wetland system. Ecol. Eng. 2018, 122, 159-168. [CrossRef]

184. Vymazal, J. Constructed wetlands for wastewater treatment. Encycl. Ecol. 2011, 45, 14-21. [CrossRef]

185. Choi, Y.-J.; Kim, L.-H.; Zoh, K.-D. Removal characteristics and mechanism of antibiotics using constructed wetlands. Ecol. Eng. 2016, 91, 85-92. [CrossRef]

186. Panja, S.; Sarkar, D. Removal of Tetracycline and Ciprofloxacin from Wastewater by Vetiver Grass (Chrysopogon zizanioides (L.) Roberty) as a Function of Nutrient Concentrations. Environ. Sci. Pollut. Res. 2020, 27, 34951-34965. [CrossRef]

187. Kurade, M.B.; Xiong, J.-Q.; Govindwar, S.P.; Roh, H.-S.; Saratale, G.D.; Jeon, B.-H.; Lim, H. Uptake and biodegradation of emerging contaminant sulfamethoxazole from aqueous phase using Ipomoea aquatica. Chemosphere 2019, 225, 696-704. [CrossRef] [PubMed]

188. Christofilopoulos, S.; Syranidou, E.; Gkavrou, G.; Manousaki, E.; Kalogerakis, N. The role of halophyteJuncus acutusL. in the remediation of mixed contamination in a hydroponic greenhouse experiment. J. Chem. Technol. Biotechnol. 2016, 91, 1665-1674. [CrossRef]

189. Alhaddad, F.A.; Abu-Dieyeh, M.H.; ElAzazi, E.-S.M.; Ahmed, T.A. Salt tolerance of selected halophytes at the two initial growth stages for future management options. Sci. Rep. 2021, 11, 1-13. [CrossRef]

190. Freedman, A.; Gross, A.; Shelef, O.; Rachmilevitch, S.; Arnon, S. Salt uptake and evapotranspiration under arid conditions in horizontal subsurface flow constructed wetland planted with halophytes. Ecol. Eng. 2014, 70, 282-286. [CrossRef]

191. Glenn, E.P.; Brown, J.J.; Blumwald, E. Salt Tolerance and Crop Potential of Halophytes. CRC Crit. Rev. Plant Sci. 1999, 18, 227-255. [CrossRef]

192. Martin, L.; Theophile, F.; Etienne, P.T.; Akoa, A. Removal of faecal bacteria and nutrients from domestic wastewater in a horizontal surface flow wetland vegetated with Echinochloa pyramidalis. Afr. J. Environ. Sci. Technol. 2012, 6, 337-345. [CrossRef]

193. Coleman, J.; Hench, K.; Garbutt, K.; Sexstone, A.; Bissonnette, G.; Skousen, J. Treatment of Domestic Wastewater by Three Plant Species in Constructed Wetlands. Water Air Soil Pollut. 2001, 128, 283-295. [CrossRef]

194. Russo, N.; Pino, A.; Toscano, A.; Cirelli, G.L.; Caggia, C.; Arioli, S.; Randazzo, C.L. Occurrence, diversity, and persistence of antibiotic resistant enterococci in full-scale constructed wetlands treating urban wastewater in Sicily. Bioresour. Technol. 2018, 274, 468-478. [CrossRef] [PubMed]

195. Lamori, J.G.; Xue, J.; Rachmadi, A.T.; Lopez, G.U.; Kitajima, M.; Gerba, C.P.; Pepper, I.L.; Brooks, J.P.; Sherchan, S. Removal of fecal indicator bacteria and antibiotic resistant genes in constructed wetlands. Environ. Sci. Pollut. Res. 2019, 26, 10188-10197. [CrossRef]

196. Maiga, Y.; von Sperling, M.; Mihelcic, J. Part 4 Management of Risk from Excreta and Wastewater. In Constructed Wetlands; Rose, J.B., Jiménez-Cisneros, B., Eds.; Michigan State University: E. Lansing, MI, USA, 2017. Available online: http://www. waterpathogens.org/book/constructed-wetlands (accessed on 27 November 2021).

197. Fang, H.; Zhang, Q.; Nie, X.; Chen, B.; Xiao, Y.; Zhou, Q.; Liao, W.; Liang, X. Occurrence and elimination of antibiotic resistance genes in a long-term operation integrated surface flow constructed wetland. Chemosphere 2017, 173, 99-106. [CrossRef]

198. Hien, P.T.; Tadashi, T.; Kazuhiro, M. Removal of Tetracycline and Tetracycline Resistance Genes from Municipal Wastewater in Microcosm Fill-and-Drain Constructed Wetlands. Jpn. J. Water Treat. Biol. 2017, 53, 11-21. [CrossRef]

199. Pazda, M.; Rybicka, M.; Stolte, S.; Bielawski, K.P.; Stepnowski, P.; Kumirska, J.; Wolecki, D.; Mulkiewicz, E.; Pazda, M Identification of Selected Antibiotic Resistance Genes in Two Different Wastewater Treatment Plant Systems in Poland: A Preliminary Study. Molecules 2020, 25, 2851. [CrossRef]

200. Song, H.-L.; Zhang, S.; Guo, J.; Yang, Y.-L.; Zhang, L.-M.; Li, H.; Yang, X.-L.; Liu, X. Vertical up-flow constructed wetlands exhibited efficient antibiotic removal but induced antibiotic resistance genes in effluent. Chemosphere 2018, 203, 434-441. [CrossRef] [PubMed]

201. Decamp, O.; Warren, A. Investigation of Escherichia coli removal in various designs of subsurface flow wetlands used for wastewater treatment. Ecol. Eng. 2000, 14, 293-299. [CrossRef]

202. Miller, J.H.; Novak, J.T.; Knocke, W.R.; Epruden, A. Survival of Antibiotic Resistant Bacteria and Horizontal Gene Transfer Control Antibiotic Resistance Gene Content in Anaerobic Digesters. Front. Microbiol. 2016, 7, 263. [CrossRef]

203. Chen, J.; Ying, G.-G.; Wei, X.-D.; Liu, Y.-S.; Liu, S.-S.; Hu, L.-X.; He, L.-Y.; Chen, Z.-F.; Chen, F.-R.; Yang, Y.-Q. Removal of antibiotics and antibiotic resistance genes from domestic sewage by constructed wetlands: Effect of flow configuration and plant species. Sci. Total Environ. 2016, 571, 974-982. [CrossRef] 
204. Šereš, M.; Innemanová, P.; Hnátková, T.; Rozkošný, M.; Stefanakis, A.; Semerád, J.; Cajthaml, T. Evaluation of Hybrid Constructed Wetland Performance and Reuse of Treated Wastewater in Agricultural Irrigation. Water 2021, 13, 1165. [CrossRef]

205. Abdel-Mohsein, H.S.; Feng, M.; Fukuda, Y.; Tada, C. Remarkable Removal of Antibiotic-Resistant Bacteria During Dairy Wastewater Treatment Using Hybrid Full-scale Constructed Wetland. Water Air Soil Pollut. 2020, 231, 1-12. [CrossRef]

206. Chen, J.; Deng, W.-J.; Liu, Y.-S.; Hu, L.-X.; He, L.-Y.; Zhao, J.-L.; Wang, T.-T.; Ying, G.-G. Fate and removal of antibiotics and antibiotic resistance genes in hybrid constructed wetlands. Environ. Pollut. 2019, 249, 894-903. [CrossRef] [PubMed]

207. Du, L.; Zhao, Y.; Wang, C.; Zhang, H.; Chen, Q.; Zhang, X.; Zhang, L.; Wu, J.; Wu, Z.; Zhou, Q. Removal performance of antibiotics and antibiotic resistance genes in swine wastewater by integrated vertical-flow constructed wetlands with zeolite substrate. Sci. Total Environ. 2020, 721, 137765. [CrossRef] [PubMed]

208. Huang, X.; Zheng, J.; Liu, C.; Liu, L.; Liu, Y.; Fan, H. Removal of antibiotics and resistance genes from swine wastewater using vertical flow constructed wetlands: Effect of hydraulic flow direction and substrate type. Chem. Eng. J. 2017, 308, 692-699. [CrossRef]

209. Liu, L.; Liu, C.; Zheng, J.; Huang, X.; Wang, Z.; Liu, Y.; Zhu, G. Elimination of veterinary antibiotics and antibiotic resistance genes from swine wastewater in the vertical flow constructed wetlands. Chemosphere 2013, 91, 1088-1093. [CrossRef] [PubMed]

210. Valipour, A.; Ahn, Y.-H. Constructed wetlands as sustainable ecotechnologies in decentralization practices: A review. Environ. Sci. Pollut. Res. 2015, 23, 180-197. [CrossRef] [PubMed]

211. Quiñónez-Dìaz, M.D.J.; Karpiscak, M.M.; Ellman, E.D.; Gerba, C.P. Removal of pathogenic and indicator microorganisms by a constructed wetland receiving untreated domestic wastewater. J. Environ. Sci. Health Part A 2001, 36, 1311-1320. [CrossRef] [PubMed]

212. Nnadozie, C.F.; Odume, O.N. Freshwater environments as reservoirs of antibiotic resistant bacteria and their role in the dissemination of antibiotic resistance genes. Environ. Pollut. 2019, 254, 113067. [CrossRef]

213. Wu, S.; Carvalho, P.N.; Müller, J.A.; Manoj, V.R.; Dong, R. Sanitation in constructed wetlands: A review on the removal of human pathogens and fecal indicators. Sci. Total Environ. 2016, 541, 8-22. [CrossRef] [PubMed]

214. Lv, Y.; Li, Y.; Liu, X.; Xu, K. The tolerance mechanism and accumulation characteristics of Phragmites australis to sulfamethoxazole and ofloxacin. Chemosphere 2020, 253, 126695. [CrossRef] [PubMed]

215. Ying, G.-G.; Toze, S.; Hanna, J.; Yu, X.-Y.; Dillon, P.J.; Kookana, R.S. Decay of endocrine-disrupting chemicals in aerobic and anoxic groundwater. Water Res. 2008, 42, 1133-1141. [CrossRef] [PubMed]

216. Han, B.; Zhang, S.; Wang, P.; Wang, C. Effects of water flow on submerged macrophyte-biofilm systems in constructed wetlands. Sci. Rep. 2018, 8, 1-12. [CrossRef] [PubMed] 